\title{
Low level laser therapy for nonspecific low-back pain (Review)
}

Yousefi-Nooraie R, Schonstein E, Heidari K, Rashidian A, Akbari-Kamrani M, Irani S, Shakiba B, Mortaz Hejri S, Mortaz Hejri S, Jonaidi A

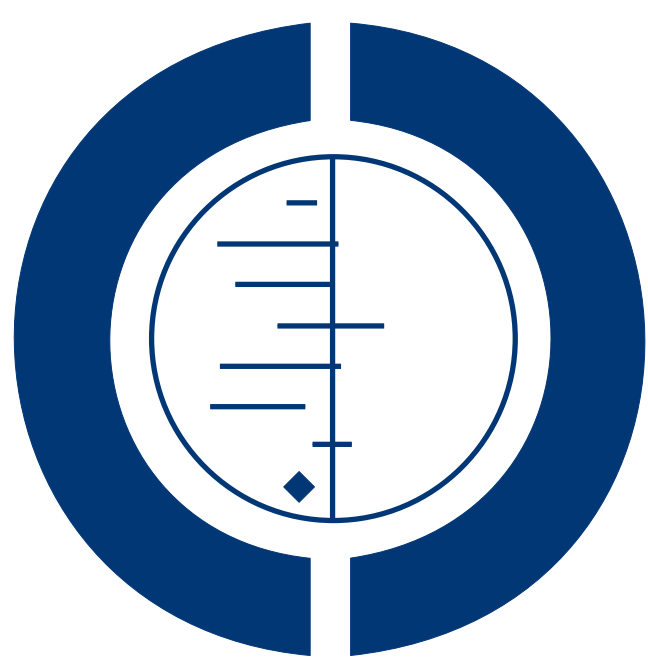

THE COCHRANE COLLABORATION $^{\circledR}$

This is a reprint of a Cochrane review, prepared and maintained by The Cochrane Collaboration and published in The Cochrane Library 2007, Issue 2

http://www.thecochranelibrary.com

\section{WILEY}




\section{TABLE OF CONTENTS}

ABSTRACT . . . . . . . . . . . . . . . . . . . . . . . . . . . . . . . . . . . . . . . 1

PLAIN LANGUAGE SUMMARY . . . . . . . . . . . . . . . . . . . . . . . . . . . . . . . . . . . 2

BACKGROUND . . . . . . . . . . . . . . . . . . . . . . . . . . . . . . . . . . . . . 2

OBJECTIVES . . . . . . . . . . . . . . . . . . . . . . . . . . . . . . . . . . . . . . . . . . . . . . . . . .

CRITERIA FOR CONSIDERING STUDIES FOR THIS REVIEW . . . . . . . . . . . . . . . . . . . . . . . $\quad$. 3

SEARCH METHODS FOR IDENTIFICATION OF STUDIES . . . . . . . . . . . . . . . . . . . . . . . . . . 3

METHODS OF THE REVIEW . . . . . . . . . . . . . . . . . . . . . . . . . . . . . . . . . . . . . . . . . . 4

DESCRIPTION OF STUDIES . . . . . . . . . . . . . . . . . . . . . . . . . . . . . . . . . . . . . . . . . 5

METHODOLOGICAL QUALITY . . . . . . . . . . . . . . . . . . . . . . . . . . . . . . . . . . . 6

RESULTS . . . . . . . . . . . . . . . . . . . . . . . . . . . . . . . . . . . . . . . . 6

DISCUSSION . . . . . . . . . . . . . . . . . . . . . . . . . . . . . . . . . . . . . . . . . .

AUTHORS' CONCLUSIONS . . . . . . . . . . . . . . . . . . . . . . . . . . . . . . . . . . . . . .

POTENTIAL CONFLICT OF INTEREST . . . . . . . . . . . . . . . . . . . . . . . . . . . . . . . . . . .

ACKNOWLEDGEMENTS . . . . . . . . . . . . . . . . . . . . . . . . . . . . . . . . . . . . . 8

SOURCES OF SUPPORT . . . . . . . . . . . . . . . . . . . . . . . . . . . . . . . . . . . . . 8

REFERENCES . . . . . . . . . . . . . . . . . . . . . . . . . . . . . . . . . . . . . . 9

TABLES . . . . . . . . . . . . . . . . . . . . . . . . . . . . . . . . . . . . . . . 11

Characteristics of included studies

Characteristics of excluded studies . . . . . . . . . . . . . . . . . . . . . . . . . . . . . . . . . . .

ADDITIONAL TABLES . . . . . . . . . . . . . . . . . . . . . . . . . . . . . . . . . . . . . . . . 15

Table 01. Search strategy for MEDLINE \& CINAHL . . . . . . . . . . . . . . . . . . . . . . . . . . . . 15

Table 02. Criteria for internal validity . . . . . . . . . . . . . . . . . . . . . . . . . . . . . . . . . . 16

Table 03. Quality assessment of included studies . . . . . . . . . . . . . . . . . . . . . . . . . . . . . 17

Table 04. Laser dosing and characteristics of included studies . . . . . . . . . . . . . . . . . . . . . . . . . 17

ANALYSES . . . . . . . . . . . . . . . . . . . . . . . . . . . . . . . . . . . . . . . . . . . . . 18

Comparison 01. LLLT versus sham intervention (grouping based on follow-up durations) . . . . . . . . . . . . . 18

Comparison 02. LLLT versus sham intervention (grouping based on laser dosing) . . . . . . . . . . . . . . . . . 18

Comparison 03. LLLT versus sham intervention (grouping based on the presence of exercise therapy) . . . . . . 19

COVER SHEET . . . . . . . . . . . . . . . . . . . . . . . . . . . . . . . . . . . . . . . . . . . 19

GRAPHS AND OTHER TABLES . . . . . . . . . . . . . . . . . . . . . . . . . . . . . . . . . . . . . . $\quad 20$

Analysis 01.01. Comparison 01 LLLT versus sham intervention (grouping based on follow-up durations), Outcome 0120 Pain (VAS)

Analysis 01.02. Comparison 01 LLLT versus sham intervention (grouping based on follow-up durations), Outcome 0221 Low back pain related disability

Analysis 01.03. Comparison 01 LLLT versus sham intervention (grouping based on follow-up durations), Outcome 0322 Range of motion (Anterior-posterior flexion)

Analysis 01.05. Comparison 01 LLLT versus sham intervention (grouping based on follow-up durations), Outcome 05 Relapse

Analysis 02.01. Comparison 02 LLLT versus sham intervention (grouping based on laser dosing), Outcome 01 Pain(VAS)-short term follow-up

Analysis 02.02. Comparison 02 LLLT versus sham intervention (grouping based on laser dosing), Outcome 02 Low back pain related disability-Short term follow-up

Analysis 02.03. Comparison 02 LLLT versus sham intervention (grouping based on laser dosing), Outcome 03 Range of motion-short term follow-up

Analysis 02.04. Comparison 02 LLLT versus sham intervention (grouping based on laser dosing), Outcome 04 RelapseIntermediate term follow-up

Analysis 03.01. Comparison 03 LLLT versus sham intervention (grouping based on the presence of exercise therapy), Outcome 01 Pain (VAS)

Analysis 03.02. Comparison 03 LLLT versus sham intervention (grouping based on the presence of exercise therapy), Outcome 02 Low back pain related disability

Low level laser therapy for nonspecific low-back pain (Review)

Copyright @ 2007 The Cochrane Collaboration. Published by John Wiley \& Sons, Ltd



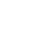


Analysis 03.03. Comparison 03 LLLT versus sham intervention (grouping based on the presence of exercise therapy),

Outcome 03 Range of motion (Anterior-posterior flexion) 


\title{
Low level laser therapy for nonspecific low-back pain (Review)
}

\author{
Yousefi-Nooraie R, Schonstein E, Heidari K, Rashidian A, Akbari-Kamrani M, Irani S, \\ Shakiba B, Mortaz Hejri Sa, Mortaz Hejri So, Jonaidi A
}

This record should be cited as:

Yousefi-Nooraie R, Schonstein E, Heidari K, Rashidian A, Akbari-Kamrani M, Irani S, Shakiba B, Mortaz Hejri Sa, Mortaz Hejri So, Jonaidi A. Low level laser therapy for nonspecific low-back pain. Cochrane Database of Systematic Reviews 2007, Issue 2. Art. No.: CD005107. DOI: 10.1002/14651858.CD005107.pub2.

This version first published online: 18 April 2007 in Issue 2, 2007.

Date of most recent substantive amendment: 12 February 2007

\section{A B S T R A C T}

\section{Background}

Low-back pain (LBP) and related disabilities are major public health problems and a major cause of medical expenses, absenteeism and disablement. Low level laser therapy (LLLT) can be used as a therapeutic intervention for musculoskeletal disorders such as back pain.

\section{Objectives}

To assess the effects of LLLT in patients with non-specific low-back pain and to explore the most effective method of administering LLLT for this disorder.

Search strategy

We searched CENTRAL (The Cochrane Library 2005, Issue 2), MEDLINE and CINAHL from their start to January 2007 and EMBASE, AMED and PEDro from their start to 2005 with no language restrictions. We screened references in the included studies and in reviews of the literature and conducted citation tracking of identified RCTs and reviews using Science Citation Index. We also contacted content experts.

\section{Selection criteria}

Only randomised controlled clinical trials (RCTs) investigating low level laser therapy as a light source treatment for non-specific lowback pain were included.

Data collection and analysis

Two authors independently assessed methodological quality using the criteria recommended by the Cochrane Back Review Group and extracted data. Consensus was used to resolve disagreements. Clinically and statistically homogeneous studies were pooled using the fixed-effect model; clinically homogeneous and statistically heterogeneous studies were pooled using the random-effects model.

\section{Main results}

Six RCTs with reasonable quality were included in the review. All of them were published in English. There is some evidence of pain relief with LLLT, compared to sham therapy for subacute and chronic low-back pain. These effects were only observed at short-term and intermediate-term follow-ups. Long-term follow-ups were not reported. There was no difference between LLLT and comparison groups for pain-related disability.

There is insufficient evidence to determine the effectiveness of LLLT on antero-posterior lumbar range of motion compared to control group in short-term follow-up. The relapse rate in the LLLT group was significantly lower than in the control group at six months follow-up period according to the findings of two trials.

\section{Authors' conclusions}

No side effects were reported. However, we conclude that there are insufficient data to draw firm conclusions.

There is a need for further methodologically rigorous RCTs to evaluate the effects of LLLT compared to other treatments, different lengths of treatment, different wavelengths and different dosages. Comparison of different LLLT treatments will be more reasonable if dose calculation methods are harmonized. 


\section{PLAIN LANGUAGE SUMMARY}

\section{Low level laser therapy for low-back pain}

Sixty to eighty per cent of people suffer from back pain at some time in their lives. Of those who develop acute low-back pain (LBP), up to $30 \%$ will go on to develop chronic LBP. The toll on individuals, families and society makes the successful management of this common, but benign condition an important goal.

Low level laser therapy (LLLT) is a therapeutic intervention for back pain that is used by some physiotherapists. Low level laser therapy is a non-invasive light source treatment that generates a single wavelength of light. It emits no heat, sound, or vibration. It is also referred to as photobiology or biostimulation. LLLT is believed to affect the function of connective tissue cells (fibroblasts), accelerate connective tissue repair and act as an anti-inflammatory agent. Lasers with different wavelengths, varying from 632 to $904 \mathrm{~nm}$, are used in the treatment of musculoskeletal disorders.

We included six small studies with a total of 318 people with non-specific low-back pain of varying durations. Three of the studies (126 people) showed that, on average, LLLT was more effective at reducing pain in the short-term (less than three months) than sham (fake) laser. However, the strength and number of treatment were varied and the amount of the pain reduction was small. Two other studies (112 people) showed that, on average, LLLT was more effective at reducing pain in the intermediate-term (six months) than sham laser. The treatment doses were similar in these two studies, but the population and number of treatments were different.

Three studies (126 people) showed that, on average, LLLT was no more effective at reducing disability in the short-term than sham laser. Once again, strength and number of treatment doses and populations were varied. Another trial (120 people) showed a reduction in pain, disability and analgesic use for the two groups who received a series of LLLT treatments compared to the group who received sham laser.

Based on these small trials, there are insufficient data to either support or refute the effectiveness of LLLT for the treatment of LBP. We had hoped to answer the questions of optimal dose, application techniques or length of treatment, but were unable to with the available evidence. There were also no trials comparing LLLT to other treatments for low-back pain. Further trials are required that are larger and look specifically at these questions.

\section{B A C K G R O U N D}

Low-back pain (LBP) and related disabilities are major public health problems and major causes of medical expenses, absenteeism and disablement (van Tulder 1995). Sixty to eighty per cent of people suffer from back pain at some time in their lives (Andersson 1997; Waddell 2004). Of all adults complaining of back pain, only about five per cent can be classified as having nerve root pain (using strict diagnostic criteria), with the remainder having back pain with or without referred leg pain, which is commonly referred to as non-specific low-back pain (Waddell 2004). Of those who develop acute LBP, up to $30 \%$ will go on to develop chronic LBP. The past 15 years have seen an intensive research effort to identify effective treatments and management strategies for lowback pain (Nachemson 2000).

Acute non-specific LBP is a benign and self-limiting condition. Once serious pathology (red flags) has been ruled out, current guidelines for the management of acute back pain recommend pain management interventions plus reassurance and advice to stay active as the interventions of choice (Waddell 2004). The aim of conservative (non-surgical) treatments for LBP is usually to relieve pain and associated disability. Recommended treatment options are diverse but there is sound evidence for only a minority of these therapies (CRD 2000; Nachemson 2000).

Low level laser therapy (LLLT) is currently used by some physiotherapists as a therapeutic intervention for musculoskeletal disorders such as back pain (Beckerman 1992; Bjordal 2003). Low level laser therapy is a light source treatment that generates light of a single wavelength. It emits no heat, sound, or vibration. Instead of producing a thermal effect, LLLT may act by non-thermal or photochemical reactions in cells. It is also referred to as photobiology or biostimulation (Basford 1989; Baxter 1991). Low level laser therapy is thought to affect fibroblast function and accelerate connective tissue repair (Kreisler 2002). It has also been reported that LLLT has anti-inflammatory effects due to its action in reducing prostaglandin synthesis (Sakurai 2000). Most LLLT lasers are Class 3a or Class 3b (Baxter 1991). Class 3a LLLTs have a power output of less than $5 \mathrm{~mW}$, and Class $3 \mathrm{~b}$ LLLTs have an output of less than $500 \mathrm{~mW}$. Low level laser therapy lasers can be either visible or invisible.

Some studies suggest that LLLT has a beneficial anti-inflammatory and pain attenuation effect in humans (Ceccherelli 1989; Mizokami 1993). Research in humans on wound healing and antiinflammatory effects of LLLT showed conflicting results (Baxter 
1991). The effectiveness of laser therapy in painful disorders is still unclear and needs to be examined more rigorously (Beckerman 1992).

\section{O B J E C T IVE S}

1) To assess the effectiveness of LLLT for the treatment of nonspecific low-back pain.

2) To explore the most effective method of administering LLLT for non-specific low-back pain, including the optimal:

- dosage

- application techniques

- length of treatment

\section{CRITERIA FOR CONSIDERING STUDIES FOR THIS REVIEW}

\section{Types of studies}

Published reports of completed randomised controlled trials (RCTs) were included. There were no restrictions on the basis of language or date of trial.

\section{Types of participants}

Trials that included male or female subjects aged 18 years and over, with acute (pain for four weeks or less), subacute (pain for one to three months) or chronic low-back pain (pain for more than three months) were included (van Tulder 2003). Low-back pain was defined as pain localised between the shoulder blades and the folds of the buttocks, with or without radiation to the legs (CRD 2000).

Trials that included subjects with low-back pain caused by specific pathological entities such as infection, metastatic diseases, neoplasms, osteoporosis, rheumatoid arthritis, fracture, inflammatory processes or radicular syndrome were excluded.

Trials that discussed musculoskeletal disorders were included if a separate analysis was reported for low-back pain.

\section{Types of intervention}

Low level laser therapy (LLLT) is a light source that generates pure light, of a single wavelength with non-thermal effects (Baxter 1991). We included reports of studies that explored the effects of all types of LLLT (Classes I, II, and III), including all wavelengths, compared to another treatment. The comparison interventions were no treatment, sham procedures or other therapeutic interventions.

\section{Types of outcome measures}

We chose outcomes for this review based on those recommended by the Cochrane Back Review Group (Deyo 1998). The primary outcomes were:

- Low-back pain measured by visual analogue scale (Huskisson 1974), box scale (Jensen 1989), McGill Pain Questionnaire (Melzack 1987) or other validated quantitative measures.

- Low-back-related disability measured by the Oswestry disability questionnaire (Fairbank 1980), Roland-Morris disability scale (Patrick 1995; Roland 1983) or other validated quantitative measures.

Secondary outcomes were:

- Overall improvement or satisfaction with treatment as rated by either participants or therapists.

- Health-related quality of life as measured by questionnaires such as the SF-12 (Ware 1996), SF-36 (Ware 1992), or EuroQoL (EuroQoL 1990).

- Return-to-work, days of absenteeism, or days of reduced activities (Deyo 1998).

- Physical examination: measuring range of motion, spinal flexibility, or muscle strength.

- Side effects, adverse effects, medication use and health care use.

To be eligible for this review, studies had to have measured at least one of the outcomes.

\section{SEARCH METHODSFOR IDENTIFICATIONOF STUDIES}

See: Cochrane Back Group methods used in reviews.

Relevant studies meeting the inclusion criteria were identified by:

- A computer-aided search of CENTRAL (The Cochrane Library 2005, issue 2), MEDLINE (1966 to January 2007), EMBASE (1988 to March 2005), CINAHL (1982 to January 2007), AMED (the Allied and Complementary Medicine Database, 1985 to March 2005) and PEDro- the physiotherapy evidence database (http://www.pedro.fhs.usyd.edu.au/index.html) (to March 2005)

- Screening references given in relevant reviews and identified RCTs.

- Citation tracking of identified RCTs and reviews using Science Citation Index

- Communication with Managing Editor, Back Review Group for additional RCTs.

- Personal contact with content experts. 
The search strategy in Additional Table 1 (Table 01) was used for MEDLINE(OVID) and CINAHL(OVID), based on van Tulder 2003.

For EMBASE, the search strategy suggested by the Back Review Group (van Tulder 2003) was used. Search words used for the PEDro database were: low back pain, back pain, backache, lumbar, dorsalgia, lumbago, laser, infrared, effectiveness, treatment, therapy. A similar process was used for AMED.

\section{METHODSOF THE REVIEW}

\section{Selecting trials for inclusion:}

All the citations identified by the above searches were downloaded into a reference manager database. Two authors with expertise in medicine, physiotherapy, laser therapy and research methods (ES and RYN), non-blinded to authors and publication journals, independently screened for inclusion, using the pre-specified criteria. If it was clear from the abstract that the study did not meet the selection criteria, it was excluded. If it was unclear from the abstract whether the study met the selection criteria, the full paper was retrieved. Two authors (MAK and SAMH), using the same selection criteria used for the abstract screening, read the full paper and made final selection decisions. Any discrepancies were resolved by discussion, followed, if necessary, by a third reviewer (RYN) if disagreement persisted.

For studies that were excluded following review of the full text, reasons for exclusion were detailed in the table of Characteristics of Excluded Studies, with a summary provided in the text of the review.

\section{Assessment of Methodological Quality:}

Two reviewers (MAK and SI) independently assessed the methodological quality of each RCT. Disagreements were dealt with by discussion and consensus in review team (ES, AR and RYN).

The 11 criteria recommended by the Back Review Group were used to assess the methodological quality of the RCTs (van Tulder 2003). Each criterion was scored as "yes", " no" or "unclear", depending on how successfully the criterion was met. The criteria for evaluating the internal validity and their operationalization are found in Additional Table 02.

If the study provided "unclear" information on methodological criteria, the authors were contacted for additional information. If no response was obtained from authors or if the information was no longer available, these criteria remained 'unclear'.

We had planned a sensitivity analysis to determine whether the overall results were the same when studies above different methodological cut-off points were synthesized (van Tulder 2003), but were unable to because of lack of studies.

\section{Data extraction:}

Two reviewers (MAK and SI) independently extracted the data on study design, participants, interventions and outcomes. Data extraction was not blinded to authors and journal of publication. Data were extracted and entered into Review Manager 4.2 for the calculation of summary statistics. Disagreements on the results of data extraction were resolved by consensus. If disagreement persisted, a third reviewer (RYN) was consulted.

Laser characteristics and dosages were recalculated based on the data available in the articles or from personal contacts. The World Association of Laser Therapy acknowledges that incomplete dosage reporting is a major problem, and recommends that review authors recalculate laser dosages of primary studies (WALT-a 2005). We calculated power, density $\left(\mathrm{mW} / \mathrm{cm}^{2}\right)$ and dose $(\mathrm{J})$ for each study. Power density for pulse lasers $\left(\mathrm{mW} / \mathrm{cm}^{2}\right)$ was calculated by multiplying the peak power pulse by the pulse duration and then by the pulse frequency and dividing the total by the spot size on the skin. Power density for lasers with continuous output $\left(\mathrm{mW} / \mathrm{cm}^{2}\right)$ was calculated by dividing the mean power by the spot size on the skin. Dose $(\mathrm{J})$ was calculated by multiplying the mean power by the treatment time per session. Authors were contacted to provide sufficient information for recalculation. Based on the recommended anti-inflammatory dosage for low level laser therapy developed by the WALT (WALTb 2005), the minimum dose for irradiating $904 \mathrm{~nm}$ lasers to the lumbar spine is $4 \mathrm{~J}$ per point. Recommended doses are based on ultrasonographic measurements of depths from skin surface and typical volume of pathological tissue and estimated optical penetration for the different laser types in Caucasians. According to these recommendations, included articles were divided into adequate and inadequate dosing subgroups (see Table 04).

\section{Analysis:}

The statistical analysis followed the recommendations of the Cochrane Handbook (CC Handbook 2005) and the Back Review Group (van Tulder 2003). The results of each RCT were plotted as point estimates with corresponding 95\% confidence intervals $(95 \% \mathrm{CI})$. Potential sources of clinical heterogeneity were identified. For studies judged as clinically homogeneous, statistical heterogeneity was tested by the $\mathrm{Q}$ test (chi-square) and $\mathrm{I}^{2}$. Clinically and statistically homogeneous studies were pooled using the fixed effect model. If data were statistically heterogeneous $(\mathrm{P}<0.1)$, reasons for heterogeneity were explored. Regardless of any evidence of statistical heterogeneity, the influence of specific differences between the RCTs was investigated. Clinically homogeneous and statistically heterogeneous studies were pooled using the random effects model. Standardized mean differences (SMD), or weighted mean differences (WMD) with 95\% CI were calculated for each outcome. Because pain, quality of life or functional status were measured with similar but not identical instruments, SMD instead of WMD were calculated. We selected a $20-\mathrm{mm}$ change in pain on a 100 -point pain scale, or $30 \%$ as the minimum clinically significant difference (MCID) for pain scores, based on Farrar 2001, who suggests an absolute difference 
of two points on 0 to 10 numeric scale and other studies that suggest that the minimum clinically significant change is not an absolute number but a range, that depends on the baseline values and duration of pain (van der Roer 2006).

To create a pooled effect measure, the team examined possible sources of clinical heterogeneity by considering:

- methodological study quality;

- population differences in age, gender;

- duration of symptoms (i.e. acute versus chronic);

- low-back pain aetiology;

- intervention type by laser class, treatment protocol, treatment duration and irradiation sites;

- outcomes [i.e. subject reports of pain and pain relief, range of motion, other measures of performance (i.e. activities of daily living, disability, function), or employment status].

Outcomes were presented separately for less than three months after randomisation (short-term follow-up), between three months and one year (intermediate follow-up), or longer than one year (long term follow-up). Subgroup analysis was performed for adequate and inadequate laser dosing according to power density and irradiated energy.

Sub-group analyses were planned for acute, sub-acute or chronic low-back pain, but because of insufficient number of studies were not carried out. Similarly, sensitivity analysis, meta-regression and publication bias tests were planned but not carried out because of insufficient numbers of studies.

When the data could not be entered in the meta-analysis because of the way the authors of the trials reported the results (for example: no information about standard deviation of the means) we performed a qualitative analysis by attributing levels of evidence to the effectiveness of low level laser therapy, taking into account the methodological quality and the outcome of the original studies (van Tulder 2003):

- Strong evidence* - consistent** findings among multiple higher quality RCTs

- Moderate evidence - consistent findings among multiple lower quality RCTs and/or one higher quality RCT

- Limited evidence - one lower quality RCT

- Conflicting evidence - inconsistent findings among multiple trials (RCTs)

\section{- No evidence - no RCTs}

* There is consensus among the Editorial Board of the Back Review Group that strong evidence can only be provided by multiple higher quality trials that replicate findings of other researchers in other settings.
** When more than $75 \%$ of the trials report the same findings.

\section{DESCRIPTIONOFSTUDIES}

In total, we found six small trials (318 people) that met the inclusion criteria.

The populations included in the trials had a diagnosis of nonspecific LBP, but differed with respect to duration of pain, previous treatments and distributions of age. One study (Longo 1991) was limited to patients with acute pain but the duration was not clear in the report and some patients might have suffered from an acute exacerbation of chronic low-back pain. Another trial included patients with LBP of at least one-month duration (Basford 1999), but the mean duration of pain in the laser and control groups was seven and 13 months respectively. In another study (Soriano 1998), patients over the age of 60 with LBP of at least three months were included. Two other trials (Gur 2003; Klein 1990) were limited to patients with chronic pain (more than one year). Toya 1994 had no limitations for the duration of pain. The lumbar pain group (41 patients) in this study consisted of lumbago (23), ischiatic neuralgia (9), lumbar musculofascial pain (2), herniated disc (3), lumbar spondylosis (4).

The types of laser, dose, duration and frequency of treatments varied among the studies. Five studies(Gur 2003; Klein 1990; Longo 1991; Soriano 1998; Toya 1994) used infrared diode lasers. Only one study used a $1060 \mathrm{~nm} \mathrm{Nd-Yag} \mathrm{laser} \mathrm{(Basford} \mathrm{1999).} \mathrm{Irradia-}$ tion energy densities were recalculated based on the information provided in the reports and if possible, directly from authors. Laser doses ranged from 0.1 J (Klein 1990) to $48.8 \mathrm{~J}$ (Basford 1999). Only three studies (Basford 1999; Soriano 1998; Toya 1994) used sufficient laser dosage according to WALT-b 2005 recommendations (Table 04). Basford 1999 used a Nd-Yag laser with some thermal effects. This study was included because the laser dose was sufficient based on WALT recommendations and the laser was considered low level laser by the authors.

In three studies (Longo 1991; Soriano 1998; Toya 1994), treatment duration was less than two weeks; in others it was about four weeks. The number of treatment sessions differed from one session in Toya 1994 to 20 sessions in Gur 2003. All studies irradiated painful areas, except Longo 1991, in which the laser targets were painful areas and trigger points. In two studies (Gur 2003; Klein 1990), exercise therapy was used in both the laser and control groups similarly. The exercise programs in these studies were considered to be comparable.

With respect to the outcome measures, pain intensity was used in all except one study (Longo 1991), and measured with a visual analogue scale (VAS) on a 0 to 100 scale. Three studies (Basford 1999; Gur 2003; Klein 1990) assessed disability using validated questionnaires and lumbar range of motion. Pain relapse rate was measured in two studies (Longo 1991; Soriano 1998). Only one 
study reported self-rated overall improvement (Longo 1991). The timing of outcome measures varied from "immediately after the end of sessions" to one year after randomisation.

Details about each included trial are given in the table of Characteristics of included studies.

\section{METHODOLOGICAL QUALITY}

The results of the methodological quality assessment are shown in Table 03. All studies were described as randomised; however the method of randomisation was explicit in only three studies (Basford 1999; Klein 1990; Toya 1994). One study (Basford 1999) used a block randomisation method for patient allocation. We remained unsure about the effectiveness of the randomisation in this study because there was a big difference in the duration of pain between the two groups (seven months in the laser group and 13 months in the control group). Allocation to treatment groups was concealed in two studies (Klein 1990; Toya 1994). Patients and care providers were blinded in all studies except one (Gur 2003). Outcome assessors were blinded in five trials (Basford 1999; Gur 2003; Klein 1990; Longo 1991; Toya 1994). The drop-out rate and loss to follow-up in the data analysed were less than $20 \%$ in all studies but one (Soriano 1998), where 21\% were excluded from final analysis in the control arm, while there were only $11 \%$ excluded from the experimental group. Two studies conducted an intention-to-treat analysis (Gur 2003; Klein 1990). For more details about the criteria met in each trial, see Table 02 . The quality scores of the included studies according to the criteria recommended by the Back Review Group's method guidelines (van Tulder 2003) ranged from six to 11 .

\section{R E S U L T S}

\section{Study selection:}

Our searches resulted in the identification of 59 reports in MEDLINE, 107 in EMBASE, 35 in CINAHL, 9 in AMED, 577 in PEDro and 28 in CENTRAL. After removing duplicates, 142 reports were screened in the next step. After exclusion of irrelevant trials, we obtained hard copies of 34 trials, including 25 English, 3 German, 2 Russian, 2 Polish, one Japanese and one Italian. Of these, 24 were primary studies, but only five trials met the inclusion criteria. Reasons for the exclusion of these studies are explained in the table of Characteristics of Excluded Studies. We contacted the primary authors of trials and experts in the field of LLLT to obtain additional information that was not reported in the published studies. One expert informally discussed this review with some other experts in the field of LLLT. One article was found in this phase (Longo 1991). When we updated the literature search to January 2007, two more potential references were located. One was excluded; the other is listed under 'Studies awaiting assess- ment', pending the receipt of additional information from the author and will be addressed in the update of this review.

\section{LLLT versus sham treatment \\ Pain:}

The pooled analysis of three trials $(\mathrm{n}=126)$ showed that LLLT was more effective than sham for patients with chronic low-back pain without neurologic symptoms for reducing pain (short-term follow-up) with a WMD -11.33, (95\% CI: -16.91 to -5.75) (Basford 1999; Gur 2003; Klein 1990). All three studies used a 100-point VAS to measure the pain. There was no significant heterogeneity for comparison of pain, indicating that the difference between LLLT and control groups was consistent across trials.

One study (Basford 1999) used adequate laser dosing and two studies (Gur 2003; Klein 1990) used inadequate laser dosages. The WMDs of pain at short-term follow-up were -16 (95\% CI: 27.95 to -4.05$)$ and -10.03 (95\%CI: -16.34 to -3.72$)$ for adequate and inadequate subgroups respectively. The same results were seen when the studies with exercise therapy as a co-intervention in both study arms (Gur 2003; Klein 1990) were compared with the study without exercise therapy (Basford 1999).

One study (Soriano 1998) measured pain with a visual analogue scale but reported the results as the percentage of pain relief graded as poor, regular, good and excellent. In this study, at the six month follow-up, $44.7 \%$ of the patients in the LLLT group and $15.2 \%$ of the control group reported excellent relief $(\mathrm{P}<0.01)$. In another study (Toya 1994), pain was graded as exacerbation, little or no change, fair, good, and excellent. The sum of the frequencies of patients with 'excellent', 'good' and 'fair' grades was defined as 'effective treatment' frequency. One day after treatment the percentage of 'effective treatment' was $94 \%(15 / 16)$ in the laser group and $48 \%(12 / 25)$ in the sham group $(\mathrm{P}=0.007)$. The pain results in intermediate-term (three months to one year) and long-term follow-ups were not reported in any other studies.

In summary, five studies (238 people) showed significant pain relief with LLLT in short term and intermediate term follow-ups. Three of them used adequate dosing as defined by WALT-b 2005. However, because of the small trials and the clinical heterogeneity of the population, treatment and outcome measurements, there are insufficient data to support or refute the efficacy of LLLT to reduce pain for individuals with subacute or chronic LBP, when compared to a sham treatment, with or without the addition of exercises as co-interventions.

\section{Disability:}

Pain-related disability was measured using the Oswestry questionnaire (Basford 1999), Modified Oswestry questionnaire (Gur 2003) and a validated 24-item questionnaire (Klein 1990). The pooled analysis of three trials $(n=126)$ failed to show a difference in short-term disability measures between the LLLT and sham groups, with a pooled SMD of -0.14 (95\% CI: -0.88 to 0.59 ) for patients with chronic low-back pain without neurologic symp- 
toms. Only one study (Basford 1999), showed a significant improvement in disability measures with a SMD of -0.81 (95\% CI: -1.36 to -0.26). It used an adequate dosing but a different type of laser and included a slightly different population of low-back pain. Gur 2003 and Klein 1990 used inadequate laser dosing, with a SMD of 0.21 (95\%CI: -0.26 to 0.68 ). The same results were seen when the studies with exercise therapy as the co-intervention in both study arms (Gur 2003; Klein 1990) were compared to the study without exercise therapy (Basford 1999).

One study (Longo 1991) measured the overall efficacy of treatment using the Ritchie scale, which includes improvement in pain, functional deficit and analgesic deviation. These symptoms completely disappeared or improved in $97.5 \%$ of patients in the LLLT group and $37.5 \%$ of the control group after one month.

In summary, four studies (278 people) measured disability. However, because of the small trials and the clinical heterogeneity of the population, treatment and outcome measurements, there are insufficient data to support or refute the efficacy of LLLT to reduce disability in individuals with (sub)acute or chronic LBP, when compared to a sham treatment, with or without the addition of exercises as co-interventions.

\section{Relapse rate:}

The percentage of relapse was reported in two trials (Longo 1991; Soriano 1998). In one trial (Longo 1991), the relapse rates were reported after one month, six months and one year after the beginning of the study. Soriano 1998 reported the relapse rate at six months follow-up. Therefore, the pooled analysis (randomeffects) of two trials $(\mathrm{n}=151)$ shows that LLLT is more effective than sham for patients with (sub)acute or chronic low-back pain without neurologic symptoms on relapse rate (intermediate-term follow-up) with RR 0.43 (95\%CI 0.28 to 0.65). Soriano 1998 used adequate laser dosage with a senior population with chronic LBP and Longo 1991 used inadequate dosage, with a workingaged population with acute LBP of undetermined duration. Both studies showed significant difference in relapse rate at intermediate-term follow-up.

\section{Secondary Outcomes:}

Three studies (Basford 1999; Gur 2003; Klein 1990) measured lumbar mobility. Two of them (Basford 1999; Gur 2003) assessed the range of motion in centimetres using the Schober test (Moll 1971). The other one (Klein 1990) measured it in degrees using a validated computerized isodynamic system. Because of the difference in the instruments the standardized mean difference was calculated. The pooled analysis of three trials $(n=126)$ using a fixedeffect method (because of the statistical homogeneity of results) failed to show a difference in anterior-posterior lumbar range of motion between the LLLT and control groups in short-term follow-up with a SMD of 0.01 (95\% CI:-0.34 to 0.36). Comparing lumbar range of motion in short-term follow-up, one study (Basford 1999) used adequate dosing, resulting in a SMD of -
0.05 (95\% CI: -0.58 to 0.47), and two studies (Gur 2003; Klein 1990) used inadequate laser dosing, ending with a pooled SMD of 0.07 ( $95 \% \mathrm{CI}:-0.40$ to 0.54$)$. The same results were seen when the studies with exercise therapy as a co-intervention in both study arms (Gur 2003; Klein 1990) were compared with the study without exercise therapy (Basford 1999).

However, as with other outcomes, because of the small trials and the clinical heterogeneity of the population, treatment and outcome measurements, there are insufficient data to support or refute the efficacy of LLLT.

One study (Basford 1999) reported the perception of benefit which was assessed using a visual analogue scale. At the one-month follow-up, the difference in the mean of perception of benefit in the laser and control groups was $9.5 \mathrm{~mm}$ (95\% CI:-1.9 to 20.9).

\section{Adverse effects:}

Two studies reported neither discomfort related to laser treatment nor an increase in pain in either group (Klein 1990; Toya 1994). In Soriano 1998, five patients in the LLLT group (two abandoned and three needed to use NSAIDS) and nine patients in the control group (three abandoned and six needed to use NSAIDS) were lost to follow-up.

Due to ambiguity and overlap of the definitions of the duration of low-back pain, subgroup analyses for acute, sub-acute and chronic low-back pain were not performed.

\section{I S C USSION}

The results for pain are based on five studies (Basford 1999; Gur 2003; Klein 1990; Soriano 1998; Toya 1994), three of which were pooled and showed a statistically significant improvement in pain relief after laser treatment in short-term and intermediate-term follow-ups. All five studies had reasonable quality (met at least 6 criteria) and all except two (Longo 1991, Toya 1994) included sub-acute or chronic non-specific low-back pain. Our findings suggest that low level laser therapy can be beneficial for pain relief in patients with chronic non-specific low-back pain. However, this improvement (WMD $-11.3 \mathrm{~mm}$ on visual analogue scale) is less than the minimum clinically significant improvement (Farrar 2001). Therefore, when one considers this, along with the clinical heterogeneity of the studies, which reduces the confidence we can have in a pooled effect size, one is forced to question the efficacy of LLLT to improve back-related symptoms, based on the current literature. Other systematic reviews on the effects of LLLT on pain showed similar small effects on pain relief. The systematic review of the effectiveness of LLLT on rheumatoid arthritis (Brosseau 2006 A) suggested that LLLT was effective at reducing pain relative to placebo (WMD -11 mm). Another systematic review investigating the effectiveness of LLLT on joint disorders (Bjordal 2003) concluded that LLLT seemed to be effective in reducing pain due 
to chronic joint disorders (WMD -29.8 mm). A Cochrane review on LLLT for osteoarthritis (Brosseau 2006 B) reported conflicting results of different studies about the effectiveness of low level lasers for pain. According to our findings, the pain relief effect of LLLT was sustained up to intermediate-term follow-up in some circumstances, as shown in the pain relapse rate findings. A possible explanation of the effects of LLLT on pain relief is its anti-inflammatory and connective tissue repair process which have been shown in some in vitro and in vivo studies (Sakurai 2000; Sattayut 1999; Skinner 1996).

We could not find any statistically significant improvement in lowback pain-related disability or range of motion after laser therapy. It may be due to the use of very low laser doses in the studies, which limits its efficacy. Only Basford 1999 study showed a significant improvement in disability measures, which used a higher laser dosage than other studies. Bjordal 2003 found that after adjustment for tissue penetration, many laser doses used in many of the trials are too low to have any significant anti-inflammatory effects at target locations. According to this limited evidence, it seems that LLLT effects are clinically modest and could not substitute for other beneficial interventions such as exercise therapy. The effectiveness of exercise and intensive multidisciplinary pain treatment programmes for chronic low-back pain is supported by strong evidence (Koes 2006).

LLLT may have some clinical effects on low-back pain in doses less than the minimum recommended doses of the World Association of Laser Therapy (WALT-b 2005). However, more research is needed on the optimal dose, wavelength and number of treatments before the recommendations could reasonably be changed.

No serious adverse events were reported in the trials included in this review, but the total sample size of included trials was small for judgment about the safety of this intervention.

Low power lasers are sometimes irradiated to acupuncture points in addition to painful areas. The rationale for laser acupuncture is vastly different from phototherapy. Instead of using the direct effect of light on tissues to initiate a physiological response, in laser acupuncture, the selection of points is based on a diagnostic and therapeutic paradigm defined in acupuncture theories (Chow 2006). Therefore laser acupuncture studies were excluded from the current review.

\section{A U THORS'CONCLUSIONS}

\section{Implications for practice}

Based on the current literature, we conclude that there are insuf- ficient data to draw firm conclusions on the efficacy of LLLT to reduce pain and disability in individuals with LBP. When infrared wavelengths are used, LLLT appears to have a small effect on pain intensity and frequency in patients suffering from chronic lowback pain, if applied to painful areas for at least two weeks. But, based on our findings, LLLT should not be substituted for other beneficial interventions such as exercise therapy.

\section{Implications for research}

There is a need for further methodologically rigorous RCTs evaluating different lengths of treatment, different wavelengths and different dosages. Comparison of different LLLT treatments will be more reasonable if dose calculation methods are harmonized. Cost-effectiveness studies are recommended.

\section{POTENTIAL CONFLICTOF I N T ER E S T}

none

\section{ACKNOWLEDGEMENTS}

We thank Jan M Bjordal, PhD. for his technical support and assistance in recalculation of laser dosage. We thank Edyta Kinel (Department of Medical Rehabilitation, Poznan, Poland), Antje Timmer (Institute of Medical Biometry and Medical Informatics, Freiburg, Germany), Simona Vecchi (Italian Cochrane Center), Maria Ishakova (Toronto), Hiroshi Tsukayama,

and Gelareh Seddigh, MD. for their invaluable assistance in translating non-English articles. We also thank Anahita Enzevai, MD. for her contribution in preparing the protocol.

We would like to thank the editors of the Cochrane Back Review group who provided constructive comments.

Finally we would like to thank Vicki Pennick, Managing Editor of the Cochrane Back Review Group for her assistance and amendments.

\section{SOURCES OF S PPORT}

\section{External sources of support}

- No sources of support supplied

Internal sources of support

- Students' Scientific Research Center,Tehran University of Medical Sciences IRAN 


\section{R E F E R E N C E S}

\section{References to studies included in this review}

Basford 1999 \{published data only\}

* Basford JR, Sheffield CG, Harmsen WS. Laser therapy: a randomized, controlled trial of the effects of low-intensity Nd:YAG laser irradiation on musculoskeletal back pain. Archives of Physical Medicine and Rehabilitation 1999;80:647-652.

Gur 2003 \{published data only\}

Gur A, Karakoc M, Cevik R, Nas K, Sarac AJ, Karakoc M. Efficacy of low power laser therapy and exercise on pain and functions in chronic low back pain. Lasers in Surgery \& Medicine 2003;32:233-238.

Klein 1990 \{published data only\}

Klein RG, Eek BC. Low-energy laser treatment and exercise for chronic low back pain: double-blind controlled trial. Archives of Physical Medicine and Rehabilitation 1990;71:34-37.

Longo 1991 \{published data only\}

Longo L, Tamburini A, Monti A. Treatment with $904 \mathrm{~nm}$ and 10600 nm laser of acute lumbago - double blind Control-laser. Journ Eur Med Laser Ass 1991;3:16-19.

Soriano 1998 \{published data only\}

Soriano F, Rios R. Gallium Arsenide laser treatment of chronic low back pain: a prospective, randomized and double blind study. Laser Therapy 1998;10:175-180.

Toya $1994\{$ \{published data only\}

Toya S, Motegi M, Inomata K, Ohshiro T, Maeda T. Report on a computer randomized double blind clinical trial to determine the effectiveness of the GaAlAs $(830 \mathrm{~nm})$ diode laser for attenuation in selected pain groups. Laser Therapy 1994;6:143-148.

\section{References to studies excluded from this review}

\section{Bertocco 2002}

Bertocco P, Montesano A, Baccalaro G, Parisio C, Vismara L. Controlled study on the efficacy of two different treatments in obese patients affected by chronic low back pain, assessed by an isokinetic device: Analysis of muscle strength and spine mobility. Europa Medicophysica 2002;38:187-193.

Gale 2006

Gale GD, Rothbart PJ, Li Y. Infrared therapy for chronic low back pain: a randomized, controlled trial. Pain Res Manag 2006;11(3): $193-6$.

Gallacchi 1981

Gallacchi G, Muller W, Plattner GR, Schnorrenberger CC. Acupuncture and laser treatment in cervical and lumbar syndrome. Schweizerische Medizinische Wochenschrift Journal Suisse de Medecine 1981; 111(37):1360-6.

Georgiev 1996

Georgiev G, Goranov K, Gatev S. Reflex therapy in discogenic lumbrosacral radiculopathies - A comparative longitudinal study. Fizikalna Kurortna i Rekhabilitatsionna Meditsina 1996;35:6-9.

Grabowski 1981

Grabowski A, Weiss M. Use of laser energy in the treatment of low back pain syndrome. Polski Tygodnik Lekarski 1981;36:1623-1625.

\section{Gurtler 1979}

Gurtler J. Acupuncture, electropuncture, and lasers in the treatment of low back pain. Schweizerische Rundschau Fur Medizin Praxis 1979; 68:149-151

Kou 1991

Kou WT. The effects of low-energy laser in the auriculotherapy in individuals with chronic low back pain. Dissertation Abstracts International 1991, issue 52:1946

\section{Kreczi 1986}

Kreczi T, Klingler D. A comparison of laser acupuncture versus placebo in radicular and pseudoradicular pain syndromes as recorded by subjective responses of patients. Acupuncture and Electro-therapeutics Research 1986;11:207-216.

Mika 1990

Mika T, Orlow H, Kuszelewski Z. Infrared laser irradiation in the treatment of low back pain syndrome. Wiad. Lek 1990;43:511-516.

Ohshiro 1992

Ohshiro T, Shirono Y. Retroactive study in 524 patients on the application of the $830 \mathrm{~nm}$ GaAlAs diode laser in low reactive-level laser therapy (LLLT) for lumbago. Laser Therapy 1992;4:121-126.

Okamoto 1989

Okamoto $\mathrm{H}$. Therapeutic effect of semiconductor laser irradiation on low-back pain. Journal of Japanese Association of Physical Medicine Balneology and Climatology 1989;52:131-145.

Pashnev 1991

Pashnev VI, Shapovalov VM. The efficacy of low-intensity pulsed laser radiation in the neurological manifestations of osteochondrosis of the lumbar spine. Voenno-Meditsinskii Zhurnal 1991;6:45-46.

\section{Snyder 1986}

Snyder ML, Bork C, Bourbon B, Trumbore D. Effect of heliumneon laser on musculoskeletal trigger points. Physical Therapy 1986 66:1087-1090.

\section{Snyder 1989}

Snyder ML, Barry AJ, Perkins AI, Soucek MD. Effects of heliumneon laser irradiation on skin resistance and pain in patients with trigger points in the neck or back. Physical Therapy 1989;69:336341

Tasaki 1991

Tasaki E, et al. Application of low power laser therapy for relief of low back pain. Proc Ninth congress of the International Society for Laser Surgery and Medicine, Anaheim, California, USA. 2-6 November 1991.

Zati 2004

Zati A, Fortuna D, Valent A, Pulvirenti F, Bilotta TW. Treatment of low back pain caused by intervertebral disk displacement: Comparison between high power laser, TENS and NSAIDs. Medicina dello Sport 2004;57:77-82.

\section{References to studies awaiting assessment}

Monticone 2004

Monticone M, Barbarino A, Testi C, Arzano S, Moschi A, Negrini S. Symptomatic efficacy of stabilizing treatment versus laser therapy for sub-acute low back pain with positive tests for sacroiliac dysfunction: 
a randomised clinical controlled trial with 1 year follow-up. Europa Medicophysica 2004;40(4):263-8.

\section{Raspopovic 2001}

Raspopovic Z, Konstantinovic L J, Tomovic M, Mihajlovic M. Influence of applied frequencies of low level laser therapy in control of acute back pain. Journal of the Neurological Sciences 2001;187(Suppl 1):Abstract No. 1-46-06.

\section{Additional references}

Andersson 1997

Andersson GBJ. The epidemiology of spinal disorders. In: J.W.Frymoyer editor(s). The adult spine: principles and practice. Second Edition. Raven Press, Ltd, 1997:93-141.

\section{Basford 1989}

Basford JR. Low-energy laser therapy: controversies and new research findings. Lasers in Surgery and Medicine 1989;9:1-5.

\section{Baxter 1991}

Baxter GD, Bell AJ, Allen JM, Ravey J. Low-level laser therapy: Current clinical practice in Northern Ireland. Physiotherapy 1991;77: $171-8$.

\section{Beckerman 1992}

Beckerman H, de Bie RA, Bouter LM, de Cuyper HJ, Oostendorp RAB. The efficacy of laser therapy for musculoskeletal and skin disorders: A criteria-based meta-analysis of randomized clinical trials. Phys Ther 1992;72:483-91.

\section{Bjordal 2003}

Jan M Bjordal1, Christian Couppé2, Roberta T Chow3, Jan Tunér4, EBjordal JM. Couppe C, Chow RT, Tuner J, Ljunggren EA. A. Systematic review of low level laser therapy with location-specific doses for pain from chronic joint disorders. Australian Journal of Physiotherapy 2003;49:107-116.

\section{Brosseau 2006 A}

Brosseau, L, Robinson, V, Wells, G, deBie, R, Gam, A, Harman, K, Morin, M, Shea, B, Tugwell, P. Low level laser therapy (Classes I, II and III) for treating rheumatoid arthritis. Cochrane Database of Systematic Reviews 2006, Issue 1. Art. No.: CD002049. DOI: 10.1002/14651858.CD002049.pub2.

Brosseau 2006 B

Brosseau, L, Gam, A, Harman, K, Morin, M, Robinson, VA, Shea, BJ, Tugwell, P, Wells, G, de Bie, RA. Low level laser therapy (Classes I, II and III) for treating osteoarthritis. Cochrane Database of Systematic Reviews 2006, Issue 1.

\section{Handbook 2005}

Higgins JPT, Green S, Editors. Cochrane Handbook for Systematic Reviews of Interventions 4.2.4. http: //www.cochrane.org/resources/handbook/hbook.htm (accessed 31st March 2005), updated March 2005.

\section{Ceccherelli 1989}

Ceccherelli F, Altafini, Castro L, Avila GL, Ambrosio F, Giron GP. Diode laser in cervical myofascial pain: a double-blind study versus placebo. Clin J Pain 1989:301-4.

\section{Chow 2006}

Chow R. Laser Acupuncture Studies Should Not Be Included in Systematic Reviews of Phototherapy. Photomedicine and Laser Surgery 2006;24:69

\section{CRD 2000}

NHS Centre for Reviews and Dissemination. Acute and chronic low back pain. Effective Health Care 2000;6(5).

\section{Deyo 1998}

Deyo RA, Battie M, Beurskens AJHM, Bombardier C, Croft P, Koes B, et al. Outcome measures for low back pain research - a proposal for standardized use. Spine 1998;23(18):2003-13.

\section{EuroQoL 1990}

EuroQoL Group. EuroQoL: A new facility for the measurement of health-related quality-of-life. Health Policy 1990;16:199-208.

\section{Fairbank 1980}

Fairbank JCT, Davies JB, Mbaot JC, O’Brien JT. The Oswestry Low Back Pain Disability Questionnaire. Physiotherapy 1980;66:271-3.

\section{Farrar 2001}

Farrar JT, Young JP Jr, LaMoureaux L, Worth JL, Poole RM. Clinical Importance of Changes in Chronic Pain Intensity Measured on an 11-point numerical rating scale. Pain 2001;94:149-58.

\section{Huskisson 1974}

Huskisson EC. Measurement of pain. Lancet 1974;2:1127-31.

\section{Jensen 1989}

Jensen ME, Karoly P, O'Riordan EF, Bland Jr F, Burns RS. A subjective experience of acute pain. An assessment of the utility index of 10 indices. Clin J Pain 1989;5(2):153-9.

\section{Koes 2006}

Koes BW, van Tulder MV, Thomas S. Diagnosis and treatment of low back pain. BMJ 2006;332:1430-1434.

\section{Kreisler 2002}

Kreisler M, Christoffers AB, Al-Haj H, Willershausen B, d'Hoedt B. Low level $809 \mathrm{~nm}$ diode laser-induced in vitro stimulation of the proliferation of human gingival fibroblasts. Lasers Surg Med 2002; 30:365-369.

\section{Melzack 1987}

Melzack R. The short-form McGill Pain Questionnaire. Pain 1987; 32:191-7.

\section{Mizokami 1993}

Mizokami T, Aoki K, Iwabuchi S, Kasai K, Yamazaki Y, Sakurai T, et al. Low Reactive Level Laser Therapy - A clinical study: Relationship between pain attenuation and the serotonergic mechanism. Laser Therapy 1993;5:165-8.

\section{Moll 1971}

Moll JMH, Wright W. Normal range of spinal mobility. Ann Rheum Dis 1971;30:381-386.

\section{Nachemson 2000}

Nachemson AL, Jonsson E. Neck and backpain. The scientific evidence of causes, diagnosis, and treatment. Philadelphia; London: Lippincott Williams \& Willkins, 2000.

Patrick 1995

Patrick DL, Deyo RA, Atlas SJ, Singer DE, Chapin A, Keller RB Assessing health-related quality-of-life in patients with sciatica. Spine 1995;20:1899-09.

\section{Roland 1983}

Roland M, Morris R. A study of the natural history of back pain. I: Development of a reliable and sensitive measure of disability in low back pain. Spine 1983;8:141-144. 


\section{Sakurai 2000}

Sakurai Y, Yamaguchi M, Abiko Y. Inhibitory effect of low-level laser irradiation on LPS-stimulated prostaglandin E2 production and cyclooxygenase-2 in human gingival fibroblasts. European Journal of Oral Science 2000;108:29-34.

\section{Sattayut 1999}

Sattayut S, Hughes F, Bradley P. $820 \mathrm{~nm}$ Gallium Aluminium Arsenide laser modulation of Prostaglandin E2 production in Interleukin-1 stimulated myoblasts. Laser Therapy 1999;11:88-95.

\section{Skinner 1996}

Skinner SM, Gage JP, Wilce PA, Saw RM. A preliminary study of the effects of laser radiation on collagen metabolism in cell culture. Aust Dent J 1996;41:188-192.

\section{van der Roer 2006}

van der Roer N, Ostelo RW, Bekkering GE, van Tulder MW, de Vet HC. Minimal clinically important change for pain intensity, functional status, and general health status in patients with nonspecific low back pain. Spine 2006;31(5):578-82.

van Tulder 1995

van Tulder MW, Koes BW, Bouter LM. A cost-of-illness study of back pain in the Netherlands. Pain 1995;62:233-40.

van Tulder 2003

van Tulder MW, Furlan A, Bombardier C, Bouter LM, the Editorial Board of the Cochrane Collaboration Back Review Group. Updated
Method Guidelines for Systematic Reviews in the Cochrane Collaboration Back Review Group. Spine 2003;28:1290-9.

\section{Waddell 2004}

Waddell G. The back pain revolution. Glasgow: Churchill \& Livingstone, 2004

\section{WALT-a 2005}

Consensus agreement on the design and conduct of systematic reviews with low level laser therapy for musculoskeletal pain and disorders. http://www.walt.nu 2005.

\section{WALT-b 2005}

World

association

of laser therapy. Recommended anti-inflammatory dosage for Low Level Laser Therapy. http://www.walt.nu/dose/index.html 2005.

\section{Ware 1992}

Ware JE, Sherbourne C. The MOS 36-item short-form Survey (SF36): I. Concept framework and item selection. Med Care 1992;30: 473-83.

\section{Ware 1996}

Ware JE, Kosinski M, Keller SD. A 12-item short form health survey. Med Care 1996;34:220-3.

* Indicates the major publication for the study

T A B LE S

\section{Characteristics of included studies}

\begin{tabular}{ll} 
Study & Basford 1999 \\
\hline Methods & Study design: RCT; Unit of allocation: Patients; Method of randomization: bloc randomized with a computer \\
generated schedule; Allocation concealment: inadequate; Blindedness: Double-masked
\end{tabular}




\section{Characteristics of included studies (Continued)}

time(seconds): $90 \mathrm{sec}$; Anatomic locations: At each of four equally spaced level (a total of 8 points) along the L2 to S3 paraspinal tissues

Control group: Irradiated with the same, but inactive laser device

\begin{tabular}{ll}
\hline Outcomes & Measurements by: An experienced and masked physician and therapist not involved in the treatment; mea- \\
& sured variables: Function(Oswestry disability questionnaire, validated), pain( visual analog scale,validated), \\
& lumbar mobility(a modification of the schober test), changes in medicatin use, activity level, perception of \\
& benefit, pain nature, and any adverse effects from treatment; Follow up sessions: sixth session, twelfth session, \\
& 28 to 35 days after the last treatment; Intention-to-treat analysis: no \\
\hline Notes & Total score: 8 \\
\hline Allocation concealment & C - Inadequate
\end{tabular}

\begin{tabular}{|c|c|}
\hline Study & Gur 2003 \\
\hline Methods & $\begin{array}{l}\text { Study design: RCT; Unit of allocation: Patients; Method of randomization: Not stated; Allocation conceal- } \\
\text { ment: not used; Blindedness: Single blind }\end{array}$ \\
\hline Participants & $\begin{array}{l}\mathrm{n}=75 \text {; } \\
\text { Recruitment of patients: not stated; Enrollment dates: May } 1999 \text { and March 2000; Age: Between the ages } \\
\text { of } 20 \text { and } 50 \text { years; Sex: Male and female; Ethnicity: Not stated; Work status: Not stated; Diagnosis of LBP: } \\
\text { self-reported criteria plus information concerning the existence of medical conditions, medication use and } \\
\text { the possibility of serious injuries.; Duration of pain: More than one year; Previous treatments: No previous } \\
\text { spinal surgery; Exclusion criteria: neurological deficits, abnormal laboratory findings, systemic and psychiatric } \\
\text { illnesses, pregnancy }\end{array}$ \\
\hline Interventions & $\begin{array}{l}\text { Two arms of the study were included: LLLT+exercise(25) and sham+exercise(25) } \\
\text { Intervention group: laser+exercise, five times a week, } 4 \text { weeks; Laser medium:Gallium-Arsenide laser; Laser } \\
\text { model: Frank Line IR 30, Fysiomed, Belgium; Wave length(nm): Not stated; Laser mode: Pulsed, } 2.1 \\
\mathrm{kHz} \text { pulse frequency; Output power: 10W, 4.2mW average power; Laser class: IIIb; Spot diameter(cm): } \\
1.1 \mathrm{~cm} \text {; Exposure time(seconds): } 4 \mathrm{~min} \text {; Anatomic locations: the L4 to L5 and L5 to S1 apophyseal capsules, } \\
\text { dorsolumbar fascia, and interspinous ligaments, as well as the gluteal fascia, posterior sacroiliac ligaments, } \\
\text { hamstrings, and gastro-soleus muscles of which pain points were palpated from the low back to the foot } \\
\text { Control group: exercise therapy: lumbar flexion and extension, knee flexion, hip adduction exercises, and } \\
\text { strength exercises of extremity muscle groups/ first session of the exercises was conducted with a physiother- } \\
\text { apist and continued at home by the patients themselves. two sessions a day, making a total of } 40 \text { sessions for } \\
4 \text { weeks }\end{array}$ \\
\hline Outcomes & $\begin{array}{l}\text { Measurements by: A physician who didn't know which therapy was taken evaluated the patients; Measured } \\
\text { variables: Functioning(Roland Disability Questionnaire (RDQ) and Modified Oswestry Disability Ques- } \\
\text { tionnaire (MODQ)), Pain( visual analogue scale (VAS)), Lumbar range of motion( Schober test), flexion } \\
\text { and lateral flexion measures; Follow up sessions: one month after therapy; Intention-to-treat analysis: no }\end{array}$ \\
\hline Notes & Total score: 6 \\
\hline Allocation concealment & B - Unclear \\
\hline
\end{tabular}

\begin{tabular}{ll} 
Study & Klein $\mathbf{1 9 9 0}$ \\
\hline Methods & $\begin{array}{l}\text { Study design: RCT; Unit of allocation: Patients; Method of randomization: a computer generated random } \\
\text { numbers table; Allocation concealment: yes; Blindedness: yes }\end{array}$ \\
\hline Participants & $\mathrm{n}=20$ \\
& Recruitment of patients: By advertisement; Enrollment dates: Not stated; Age: Between the ages of 21 and \\
& 55 years; Sex: Male and female; Ethnicity: Not stated; Work status: Not stated; Diagnosis of LBP: Clinical \\
& features of back pain with prolonged maintenance of one posture, such as prolonged sitting, standing, or \\
& bending and temporary relief of symptoms witrh changing positions or walking; Duration of pain: More than
\end{tabular}




\section{Characteristics of included studies (Continued)}

one year; Previous treatments: No prior back surgery; Exclusion criteria: Acute exacerbation of chronic LBP, not pregnant, no prior surgery, not $>10$ pounds overweight, not involved in litigation or disability claims

Interventions Both arms of the trial were included: LLLT+exercise(10) and sham+exercise(10).

Intervention group: laser+exercise, three times a week , 4 weeks; Laser medium:Ga-As laser; Laser model: Omniprobe (laser biostimulation unit); Wave length(nm): 904nm; Laser mode: Pulsed, $1 \mathrm{kHz}$ pulse frequency, $200 \mathrm{nsec}$ pulse duration; Output power: 2W; Laser class: I; Spot diameter $(\mathrm{cm}): 1.1 \mathrm{~cm}$ in each head with 10 heads; Exposure time(seconds): 240sec (4min) for each point $20 \mathrm{~min}$ of total stimulation time for each patient]; Anatomic locations: external over a series of standardized fields designed to include the L4 to L5 \& L5 to S1 apophyseal capsules, dorsolumbar fascia, interspinous ligaments, gluteal fascia, posterior sacroiliac ligaments

Control group: Home Exercise program: 50 full-forward flexion exercises performed in standing position followed by 25 extension exercises twice a day, walk briskly: $20 \mathrm{~min}$ a day, 2 sets of knee flexion coupled with hip abduction each day. Exercises were to be started on the first day of the study and countinuoud at least untill completion of all objective and subjective measurements.

Outcomes Measurements by: a blinded physical therapist ; Measured variables: Disability score( a questionnaire of 24 items(validated)), Pain(VAS $(0-7.5 \mathrm{~cm})$ ), Lumbar function (range of motion/ isometric torque/ isodynamic velocities), the isotechnologies B100(a commercially available computerized isodynamic system)/ (validated); Follow up sessions: one month after therapy; Intention-to-treat analysis: yes

\begin{tabular}{ll}
\hline Notes & Total score: 11 \\
\hline Allocation concealment & A-Adequate \\
\hline
\end{tabular}

\begin{tabular}{|c|c|}
\hline Study & Longo 1991 \\
\hline Methods & $\begin{array}{l}\text { Study design: RCT; Unit of allocation: Patients; Method of randomization: Not stated; Allocation conceal- } \\
\text { ment:unclear; Blindedness: yes }\end{array}$ \\
\hline Participants & $\begin{array}{l}\mathrm{n}=120 \text { ( } 40 \text { to each of } 3 \text { groups), but only used } 2 \text { groups in this review, therefore } \mathrm{n}=80 \\
\text { Recruitment of patients: Not stated; Enrollment dates: Not stated; Age: Between the ages of } 40 \text { and } 65 \text { years; } \\
\text { Sex: Male and female; Ethnicity: Not stated; Work status: Not stated; Diagnosis of LBP: acute lumbago with } \\
\text { degenerative or traumatic lesions visible in X-ray and without obvious signs of neurologic deficit ; Duration } \\
\text { of pain: acute(?); Previous treatments: No previous therapy which interfers with the results of the experiment } \\
\text {; Exclusion criteria: Fracture, luxation, hernia of the nucleus pulposus }\end{array}$ \\
\hline \multirow[t]{2}{*}{ Interventions } & $\begin{array}{l}\text { Two arms of the trial were included: LLLT(40) and sham(40). } \\
\text { Intervention group: laser, Treatment begun within } 24 \mathrm{hr} \text { of the onset of the symptoms once a day for } \\
5 \text { days, then another } 5 \text { on alternative days; Laser medium:Diode laser ; Laser model: Not stated; Wave } \\
\text { length(nm): } 904 \mathrm{~nm} \text {; Laser mode: Pulsed, } 3 \mathrm{kHz} \text { pulse frequency, } 200 \mathrm{nsec} \text { pulse duration; Output power: } \\
\text { peak power } 72 \mathrm{~W}(27 \mathrm{~W} \text { ?); Laser class: Not stated; Spot diameter }(\mathrm{cm}): 0.2 \mathrm{~cm}(1 \mathrm{~cm} 2 \mathrm{spot} \text { area using lens cor- } \\
\text { rection); Exposure time(seconds): } 5 \mathrm{~min} / \mathrm{cm} 2 \text { (of every radiation); Anatomic locations: Intervertebral holes, } \\
\text { possible trigger points }\end{array}$ \\
\hline & Control group: simulated laser irradiation \\
\hline Outcomes & $\begin{array}{l}\text { Measurements by: two blinded doctors; Measured variables: spontenous or induced pain( Ritchie scale for } \\
\text { intensity of pain), level of reflected analgesic vertebral deviation(the angel of inclination in an AP X-ray } \\
\text { (validation not mentioned)), functional limitation (percentage of normal movement of the sacral-lumbar area } \\
\text { (validation not mentioned)); Follow up sessions: after } 3 \text { applications, after } 5 \text { applications, after one month, } \\
\text { after six months, after one year; Intention-to-treat analysis: no }\end{array}$ \\
\hline Notes & Total score: 7 \\
\hline Allocation concealment & B - Unclear \\
\hline
\end{tabular}

Study Soriano 1998

Methods Study design: RCT; Unit of allocation: Patients; Method of randomization: Not stated; Allocation concealment: no; Blindedness: yes 


\section{Characteristics of included studies (Continued)}

Participants $\quad$ randomized $=85$; analyzed $=71$ (5/43 dropped out from experimental group; 9/42 dropped out from control group)

Recruitment of patients: Not stated; Enrollment dates: Not stated; Age: more than 60 years; Sex: Male and female; Ethnicity: Not stated; Work status: Not stated; Diagnosis of LBP: Not stated ; Duration of pain: $>3$ months; Previous treatments: The use of analgesic drugs and physical therapy was excluded in both groups, a wash-out period of 5 days was done on any patient on NSAIDs; Exclusion criteria: any suspicious of cancer, any suspicious of osteomyelitis, any suspicious of gout, any suspicious of paget's disease, any suspicious of collagen disease, symptoms or signs of neurologic deficits in the lower limbs, usage of long acting corticoids within the prior 30 days

Interventions Both arms of the trial were included: LLLT(38) and sham(33).

Intervention group: laser, five sessions a week for 2 weeks; Laser medium:Ga-As diode laser ; Laser model: Not stated; Wave length(nm): 904nm; Laser mode: Pulsed, $10 \mathrm{kHz}$ pulse frequency, $200 \mathrm{nsec}$ pulse duration; Output power: peak power $20 \mathrm{~W}$, average power: $40 \mathrm{~mW}$; Laser class: Not stated; Spot diameter $(\mathrm{cm}): 1.1 \mathrm{~cm}$; Exposure time(seconds): 100; Anatomic locations: On painful area

Control group: Sham irradiation with a deactivated laser radiation, but the electrical circuit, timer and alarm worked as usual so that to all intents and purposes it was exactly identical to the real system.

Outcomes

Measurements by: Not stated; Measured variables: pain(VAS), Radiologic findings (osteopoenia, osteophytes, narrowing of disc spaces, spondylolisthesis grade 1), physical examination; Follow up sessions: every 1 month for six months; Intention-to-treat analysis: no

\begin{tabular}{ll}
\hline Notes & Total score: 6 \\
\hline Allocation concealment & B - Unclear \\
\hline
\end{tabular}

Study

Methods

Participants

\section{Toya 1994}

Study design: RCT; Unit of allocation: Patients; Method of randomization: a computer generated schedule; Allocation concealment: adequate; Blindedness: Double-blinded

randomized $=130$; analyzed 115,41 of whom had LBP and were included in this review

Recruitment of patients: patients attending their respective institution on an outpatient basis; Enrollment dates: Not stated; between the ages of 18 to 82y; Sex: Male and female; Ethnicity: Not stated; Work status: Not stated; Diagnosis of LBP: Not stated, Lumbar pain group(41 patients) consisted of Lumbago(23), Ischiatic neuralgia(9), Lumbar musculofascial pain(2), herniated disc(3), lumbar spondylosis(4); Duration of pain: not stated; Previous treatments: no limitations, a wash-out period was done on any patient on medications; Exclusion criteria: not stated

Interventions

Both arms of the trial were included: LLLT(16) and sham(25).

Intervention group: laser, single session, no other treatments allowed; Laser medium:Ga-Al-As diode laser ; Laser model: OhLase-3D1(Proli, Japan); Wave length(nm): 830nm; Laser mode: continuous; Output power: $60 \mathrm{~mW}$; Laser class: Not stated; Spot diameter(cm): $0.16 \mathrm{~cm}$; Exposure time(seconds): 5 to 10 min (mean of $9.18 \mathrm{~min})$; Anatomic locations: On painful area

Control group: Sham irradiation with a deactivated laser radiation, but the electrical circuit, timer and alarm worked as usual and controlled by a locked remote centralised computer

Outcomes

Measurements by: a blinded therapist ; Measured variables: pain graded as exacerbation, little or no change, fair, good, excellent; Follow up sessions: immediately and one day after treatment; Intention-to-treat analysis: no

Notes Total score: 9

Allocation concealment A-Adequate

Low level laser therapy for nonspecific low-back pain (Review)

Copyright (c) 2007 The Cochrane Collaboration. Published by John Wiley \& Sons, Ltd 


\section{Characteristics of excluded studies}

\begin{tabular}{ll} 
Study & Reason for exclusion \\
\hline Bertocco 2002 & No LLLT group \\
\hline Gale 2006 & no LLLT group. Infrared therapy \\
\hline Gallacchi 1981 & no clinically important outcomes reported. \\
\hline Georgiev 1996 & Radiculopathy, low-back pain caused by specific pathological entities \\
\hline Grabowski 1981 & Not RCT or CCT \\
\hline Gurtler 1979 & Not RCT or CCT \\
\hline Kou 1991 & Laser acupuncture \\
\hline Kreczi 1986 & No separate analysis for Low back pain \\
\hline Mika 1990 & Not RCT or CCT \\
\hline Ohshiro 1992 & Not RCT or CCT \\
\hline Okamoto 1989 & No separate analysis for Low back pain \\
\hline Pashnev 1991 & Radiculopathy, low-back pain caused by specific pathological entities. No separate analysis for Low back pain \\
\hline Snyder 1986 & No separate analysis for Low back pain \\
\hline Snyder 1989 & No separate analysis for Low back pain \\
\hline Tasaki 1991 & Not RCT or CCT \\
\hline Zati 2004 & High power laser, Disc displacement \\
\hline
\end{tabular}

\section{A D D I T I O NAL TABLES}

\section{Table 01. Search strategy for MEDLINE \& CINAHL}

1.randomized controlled trial.pt.

2.controlled clinical trial.pt

3.Randomized Controlled Trials/

4.Random Allocation/

5.Double-Blind Method/

6.Single-Blind Method/

7.or/1-6

8.Animal/ not Human/

9.7 not 8

10.clinical trial.pt.

11.exp Clinical Trials/

12.(clin\$ adj25 trial\$).tw.

13. ( (singl\$ or doubl $\$$ or trebl $\$$ or tripl $\$$ ) adj25 (blind $\$$ or mask $\$)$ ).tw.

14.Placebos/

15.placebo $\$ . t w$.

16.random\$.tw.

17.Research Design/

18.(latin adj square).tw.

19. or/10-18

20.19 not 18 
Table 01. Search strategy for MEDLINE \& CINAHL (Continued)

21.20 not 9

22. Comparative Study/

23.exp Evaluation Studies/

24.Follow-Up Studies/

25.Prospective Studies?

26. (control\$ or prospective\$ or Volunteer\$).tw.

27.Cross-Over Studies/

28.or/22-27

29.28 not 8

30.29 not (9 or 21$)$

31.9 or 21 or 30

32. back pain.sh

33. low back pain.sh

34. back pain.ti,ab

35. backache.ti,ab

36. exp back pain/

37. dorsalgia.ti,ab

38. lumbago.ti,ab

39. (lumbar adj pain).ti,ab

40.or/32-39

41. laser\$.sh

42. laser\$.tw

43. exp light/

44. infrared.tw

45. ultraviolet.tw

46. monochromatic.tw

47.or/41-46

48.31 and 40 and 47

\section{Table 02. Criteria for internal validity}

\section{Criteria}

A Was the method of randomization adequate? A random (unpredictable) assignment sequence.

B Was the treatment allocation concealed? Assignment generated by an independent person not responsible for determining the eligibility of the patients. This person has no information about the persons included in the trial and has no influence on the assignment sequence or on the decision about eligibility of the patient.

$\mathrm{C}$ Were the groups similar at baseline regarding the most important prognostic indicators? In order to receive a "yes", groups have to be similar at baseline characteristics.

$\mathrm{D}$ Was the patient blinded to the intervention? The reviewer determines if enough information about the blinding is given in order to score a "yes."

E Was the care provider blinded to the intervention? The reviewer determines if enough information about the blinding is given in order to score a "yes."

F Was the outcome assessor blinded to the intervention? The reviewer determines if enough information about the blinding is given in order to score a "yes."

G Were co-interventions avoided or similar? Co-interventions should either be avoided in the trial design or similar between the index and control groups.

$\mathrm{H}$ Was the compliance acceptable in all groups? The reviewer determines if the compliance to the interventions is acceptable.

I Was the drop-out rate described and acceptable? The number of participants who were included in the study but did not complete the observation period or were not included in the analysis must be described and reasons given. If the percentage of withdrawals and

Low level laser therapy for nonspecific low-back pain (Review)

Copyright @ 2007 The Cochrane Collaboration. Published by John Wiley \& Sons, Ltd 
Table 02. Criteria for internal validity (Continued)

\section{Criteria}

drop-outs does not exceed $20 \%$ for short-term follow-up and $30 \%$ for long-term follow-up and does not lead to substantial bias a "yes" is scored.

$\mathrm{J}$ Was the timing of the outcome assessment in all groups similar? Timing of outcome assessment should be identical for all intervention groups and for all important outcome assessments.

K Did the analysis include an intention-to-treat analysis? All randomized patients are reported/analyzed in the group they were allocated to by randomization for the most important moments of effect measurement (minus missing values) irrespective of noncompliance and co-interventions.

Table 03. Quality assessment of included studies

\begin{tabular}{|c|c|c|c|c|c|c|c|c|c|}
\hline $\begin{array}{l}\text { Name of } \\
\text { study }\end{array}$ & $\begin{array}{l}\text { Randomi- } \\
\text { sation }\end{array}$ & $\begin{array}{l}\text { Conc. of } \\
\text { allocation }\end{array}$ & $\begin{array}{l}\text { Baseline } \\
\text { assess- } \\
\text { ments }\end{array}$ & Blinding & $\begin{array}{l}\text { Co-inter- } \\
\text { vention }\end{array}$ & $\begin{array}{l}\text { Compli- } \\
\text { ance }\end{array}$ & $\begin{array}{l}\text { Drop-out } \\
\text { rates }\end{array}$ & $\begin{array}{l}\text { Outcome } \\
\text { assess- } \\
\text { ment }\end{array}$ & $\begin{array}{l}\text { Total } \\
\text { score }\end{array}$ \\
\hline $\begin{array}{l}\text { Basford } \\
1999\end{array}$ & Adequate & No & No & $\begin{array}{l}\text { Patients, } \\
\text { providers, } \\
\text { assessors }\end{array}$ & Avoided & Acceptable & Acceptable & $\begin{array}{l}\text { similar } \\
\text { timing: +; } \\
\text { intention- } \\
\text { to-treat: - }\end{array}$ & 8 \\
\hline Gur 2003 & $\begin{array}{l}\text { inadequate } \\
\text { informa- } \\
\text { tion }\end{array}$ & No & Yes & assessors & Avoided & Acceptable & Acceptable & $\begin{array}{l}\text { similar } \\
\text { timing: +; } \\
\text { intention- } \\
\text { to-treat: - }\end{array}$ & 6 \\
\hline $\begin{array}{l}\text { Klein } \\
1990\end{array}$ & Adequate & Yes & Yes & $\begin{array}{l}\text { Patients, } \\
\text { providers, } \\
\text { assessors }\end{array}$ & Avoided & Acceptable & Acceptable & $\begin{array}{l}\text { similar } \\
\text { timing: +; } \\
\text { intention- } \\
\text { to-treat: + }\end{array}$ & 11 \\
\hline $\begin{array}{l}\text { Longo } \\
1991\end{array}$ & $\begin{array}{l}\text { inadequate } \\
\text { informa- } \\
\text { tion }\end{array}$ & Unclear & Unclear & $\begin{array}{l}\text { Patients, } \\
\text { providers, } \\
\text { assessors }\end{array}$ & Avoided & Acceptable & Acceptable & $\begin{array}{l}\text { similar } \\
\text { timing: +; } \\
\text { intention- } \\
\text { to-treat: - }\end{array}$ & 7 \\
\hline $\begin{array}{l}\text { Soriano } \\
1998\end{array}$ & $\begin{array}{l}\text { inadequate } \\
\text { informa- } \\
\text { tion }\end{array}$ & No & Yes & $\begin{array}{l}\text { Patients, } \\
\text { providers }\end{array}$ & Avoided & Acceptable & $\begin{array}{l}\text { More than } \\
20 \% \text { in } \\
\text { Control } \\
\text { group }\end{array}$ & $\begin{array}{l}\text { similar } \\
\text { timing: +; } \\
\text { intention- } \\
\text { to-treat: - }\end{array}$ & 6 \\
\hline Toya 1994 & Adequate & Yes & Unclear & $\begin{array}{l}\text { Patients, } \\
\text { providers, } \\
\text { assessors }\end{array}$ & Avoided & Acceptable & Acceptable & $\begin{array}{l}\text { similar } \\
\text { timing: +; } \\
\text { intention- } \\
\text { to-treat: - }\end{array}$ & 9 \\
\hline
\end{tabular}

Table 04. Laser dosing and characteristics of included studies

\begin{tabular}{|c|c|c|c|c|c|c|c|}
\hline $\begin{array}{l}\text { Name of } \\
\text { study }\end{array}$ & $\begin{array}{l}\text { Laser } \\
\text { medium }\end{array}$ & $\begin{array}{l}\text { Wave length } \\
\text { (nm) }\end{array}$ & Laser mode & $\begin{array}{l}\text { Output } \\
\text { power }\end{array}$ & $\begin{array}{l}\text { Power } \\
\text { density }\end{array}$ & $\begin{array}{l}\text { Dose } \\
\text { (J/point) }\end{array}$ & $\begin{array}{l}\text { Adequacy } \\
\text { (WALT) }\end{array}$ \\
\hline Basford 1999 & Nd-YAG & 1060 & Continuous & $1626 \mathrm{~mW}$ & $542 \mathrm{~mW} / \mathrm{cm} 2$ & $48.8 \mathrm{~J}$ & Yes \\
\hline Gur 2003 & Gallium- & Not stated & Pulsed, 2.1 & peak power & $4.4 \mathrm{~mW} / \mathrm{cm} 2$ & $1 \mathrm{~J}$ & No \\
\hline
\end{tabular}


Table 04. Laser dosing and characteristics of included studies (Continued)

\begin{tabular}{|c|c|c|c|c|c|c|c|}
\hline $\begin{array}{l}\text { Name of } \\
\text { study }\end{array}$ & $\begin{array}{l}\text { Laser } \\
\text { medium }\end{array}$ & $\begin{array}{l}\text { Wave length } \\
(\mathrm{nm})\end{array}$ & Laser mode & $\begin{array}{l}\text { Output } \\
\text { power }\end{array}$ & $\begin{array}{l}\text { Power } \\
\text { density }\end{array}$ & $\begin{array}{l}\text { Dose } \\
\text { (J/point) }\end{array}$ & $\begin{array}{l}\text { Adequacy } \\
\text { (WALT) }\end{array}$ \\
\hline & Arsenide & & $\begin{array}{l}\mathrm{kHz} \text { pulse } \\
\text { frequency }\end{array}$ & $10 \mathrm{~W}$ & & & \\
\hline Klein 1990 & $\begin{array}{l}\text { Gallium- } \\
\text { Arsenide }\end{array}$ & 904 & $\begin{array}{l}\text { Pulsed, } 1 \\
\mathrm{kHz} \text { pulse } \\
\text { frequency, } \\
200 \text { nsec } \\
\text { pulse duration }\end{array}$ & $\begin{array}{l}\text { peak power } \\
2 \mathrm{~W}\end{array}$ & $0.4 \mathrm{~mW} / \mathrm{cm} 2$ & $0.1 \mathrm{~J}$ & No \\
\hline Longo 1991 & $\begin{array}{l}\text { Gallium- } \\
\text { Arsenide }\end{array}$ & 904 & $\begin{array}{l}\text { Pulsed, } 3 \\
\mathrm{kHz} \text { pulse } \\
\text { frequency, } \\
200 \text { nsec } \\
\text { pulse duration }\end{array}$ & $\begin{array}{l}\text { peak power } \\
72 \mathrm{~W}(27 \mathrm{~W} ?)\end{array}$ & $10 \mathrm{~mW} / \mathrm{cm} 2$ & $3 \mathrm{~J}$ & No \\
\hline Soriano 1998 & $\begin{array}{l}\text { Gallium- } \\
\text { Arsenide }\end{array}$ & 904 & $\begin{array}{l}\text { Pulsed, } 10 \\
\mathrm{kHz} \text { pulse } \\
\text { frequency, } \\
200 \text { nsec } \\
\text { pulse duration }\end{array}$ & $\begin{array}{l}\text { peak power } \\
20 \mathrm{~W}\end{array}$ & $40 \mathrm{~mW} / \mathrm{cm} 2$ & $4 \mathrm{~J}$ & Yes \\
\hline Toya 1994 & Ga-Al-As & 830 & continuous & $60 \mathrm{~mW}$ & $\begin{array}{l}3000 \\
\mathrm{~mW} / \mathrm{cm} 2\end{array}$ & $18-36 \mathrm{~J}$ & Yes \\
\hline
\end{tabular}

\section{A N A L Y S E S}

\section{Comparison 01. LLLT versus sham intervention (grouping based on follow-up durations)}

\begin{tabular}{|c|c|c|c|c|}
\hline Outcome title & $\begin{array}{l}\text { No. of } \\
\text { studies }\end{array}$ & $\begin{array}{c}\text { No. of } \\
\text { participants }\end{array}$ & Statistical method & Effect size \\
\hline 01 Pain (VAS) & 3 & 126 & Weighted Mean Difference (Fixed) 95\% CI & $\begin{array}{l}-11.33[-16.91,- \\
5.75]\end{array}$ \\
\hline 02 Low back pain related disability & 3 & 126 & $\begin{array}{l}\text { Standardised Mean Difference (Random) 95\% } \\
\text { CI }\end{array}$ & $-0.14[-0.88,0.59]$ \\
\hline $\begin{array}{l}03 \text { Range of motion (Anterior- } \\
\text { posterior flexion) }\end{array}$ & 3 & 126 & Standardised Mean Difference (Fixed) 95\% CI & $0.01[-0.34,0.36]$ \\
\hline 05 Relapse & & & Relative Risk (Random) 95\% CI & Subtotals only \\
\hline
\end{tabular}

Comparison 02. LLLT versus sham intervention (grouping based on laser dosing)

\begin{tabular}{|c|c|c|c|c|}
\hline Outcome title & $\begin{array}{l}\text { No. of } \\
\text { studies }\end{array}$ & $\begin{array}{c}\text { No. of } \\
\text { participants }\end{array}$ & Statistical method & Effect size \\
\hline $\begin{array}{l}01 \text { Pain(VAS)-short term follow- } \\
\text { up }\end{array}$ & 3 & 126 & Weighted Mean Difference (Fixed) 95\% CI & $\begin{array}{l}-11.33[-16.91,- \\
5.75]\end{array}$ \\
\hline $\begin{array}{l}02 \text { Low back pain related } \\
\text { disability-Short term follow-up }\end{array}$ & 3 & 126 & $\begin{array}{l}\text { Standardised Mean Difference (Random) 95\% } \\
\text { CI }\end{array}$ & $-0.14[-0.88,0.59]$ \\
\hline $\begin{array}{l}03 \text { Range of motion-short term } \\
\text { follow-up }\end{array}$ & 3 & 126 & Standardised Mean Difference (Fixed) $95 \%$ CI & $0.01[-0.34,0.36]$ \\
\hline
\end{tabular}


Comparison 03. LLLT versus sham intervention (grouping based on the presence of exercise therapy)

\begin{tabular}{|c|c|c|c|c|}
\hline Outcome title & $\begin{array}{l}\text { No. of } \\
\text { studies }\end{array}$ & $\begin{array}{c}\text { No. of } \\
\text { participants }\end{array}$ & Statistical method & Effect size \\
\hline 01 Pain (VAS) & 3 & 126 & Weighted Mean Difference (Fixed) 95\% CI & $\begin{array}{l}-11.33[-16.91,- \\
5.75]\end{array}$ \\
\hline 02 Low back pain related disability & 3 & 126 & $\begin{array}{l}\text { Standardised Mean Difference (Random) 95\% } \\
\text { CI }\end{array}$ & $-0.14[-0.88,0.59]$ \\
\hline $\begin{array}{l}03 \text { Range of motion ( Anterior- } \\
\text { posterior flexion) }\end{array}$ & 3 & 126 & Standardised Mean Difference (Fixed) 95\% CI & $0.01[-0.34,0.36]$ \\
\hline
\end{tabular}

\section{COVER SHEET}

Title

Authors

\section{Contribution of author(s)}

Issue protocol first published

Review first published

Date of most recent amendment

Date of most recent SUBSTANTIVE amendment

\section{What's New}

Date new studies sought but none found

Date new studies found but not yet included/excluded
Low level laser therapy for nonspecific low-back pain

Yousefi-Nooraie R, Schonstein E, Heidari K, Rashidian A, Akbari-Kamrani M, Irani S, Shakiba B, Mortaz Hejri Sa, Mortaz Hejri So, Jonaidi A

Yousefi-Nooraie R, Schonstein E, Heidari K, Rashidian A, Akbari Kamrani M, Irani S, Shakiba B, Mortaz Hejri Sa, Mortaz Hejri So, Jonaidi A,

conceptualization of topic and registration of title: Yousefi-Nooraie R, Schonstein E, Heidari K, Rashidian A, Akbari Kamrani M, Irani S, Shakiba B, Mortaz Hejri Sa, Mortaz Hejri So, Jonaidi A

development of review team:Yousefi-Nooraie R

development of protocol:Yousefi-Nooraie R, Schonstein E, Heidari K, Akbari Kamrani M, Irani S, Shakiba B, Mortaz Hejri Sa, Mortaz Hejri So, Rashidian A, Jonaidi A literature search: Yousefi-Nooraie R, Schonstein E, Heidari K, Shakiba B selection of trials: Yousefi-Nooraie R, Schonstein E quality assessment of trials: Mortaz Hejri Sa, Akbari Kamrani M, Heidari K, Shakiba B data extraction: Yousefi-Nooraie R, Akbari Kamrani M, Irani S data analysis: Yousefi-Nooraie R, Akbari Kamrani M interpretation of results: Yousefi-Nooraie R, Schonstein E, Heidari K, Rashidian A, Akbari Kamrani M, Irani S, Shakiba B, Mortaz Hejri Sa, Mortaz Hejri So, Jonaidi A writing of review: Yousefi-Nooraie R, Rashidian A, Schonstein E, Heidari K, Akbari Kamrani M, Irani S, Shakiba B, Mortaz Hejri Sa, Mortaz Hejri So, Jonaidi A

review of final manuscripts of protocol and review: Yousefi-Nooraie R, Rashidian A, Schonstein E, Heidari K, Akbari Kamrani M, Irani S, Shakiba B, Mortaz Hejri Sa, Mortaz Hejri So, Jonaidi A

$2005 / 1$

$2007 / 2$

21 February 2007

12 February 2007

Information not supplied by author

Information not supplied by author

Information not supplied by author 
Date new studies found and included/excluded

Date authors' conclusions section amended

Contact address
12 January 2007

Information not supplied by author

Dr Reza Yousefi-Nooraie

Research Tutor

Centre for Academic and Health Policies

Tehran University of Medical Sciences

P.O. Box 13145-967

Tehran

IRAN

E-mail: ryousefi@razi.tums.ac.ir

Tel: +9821 6901838

10.1002/14651858.CD005107.pub2

CD005107

Cochrane Back Group

HM-BACK

\section{Editorial group code}

GRAPHS ANDOTHER TABLES

\section{Analysis 01.01. Comparison 0I LLLT versus sham intervention (grouping based on follow-up durations), Outcome 0 I Pain (VAS)}

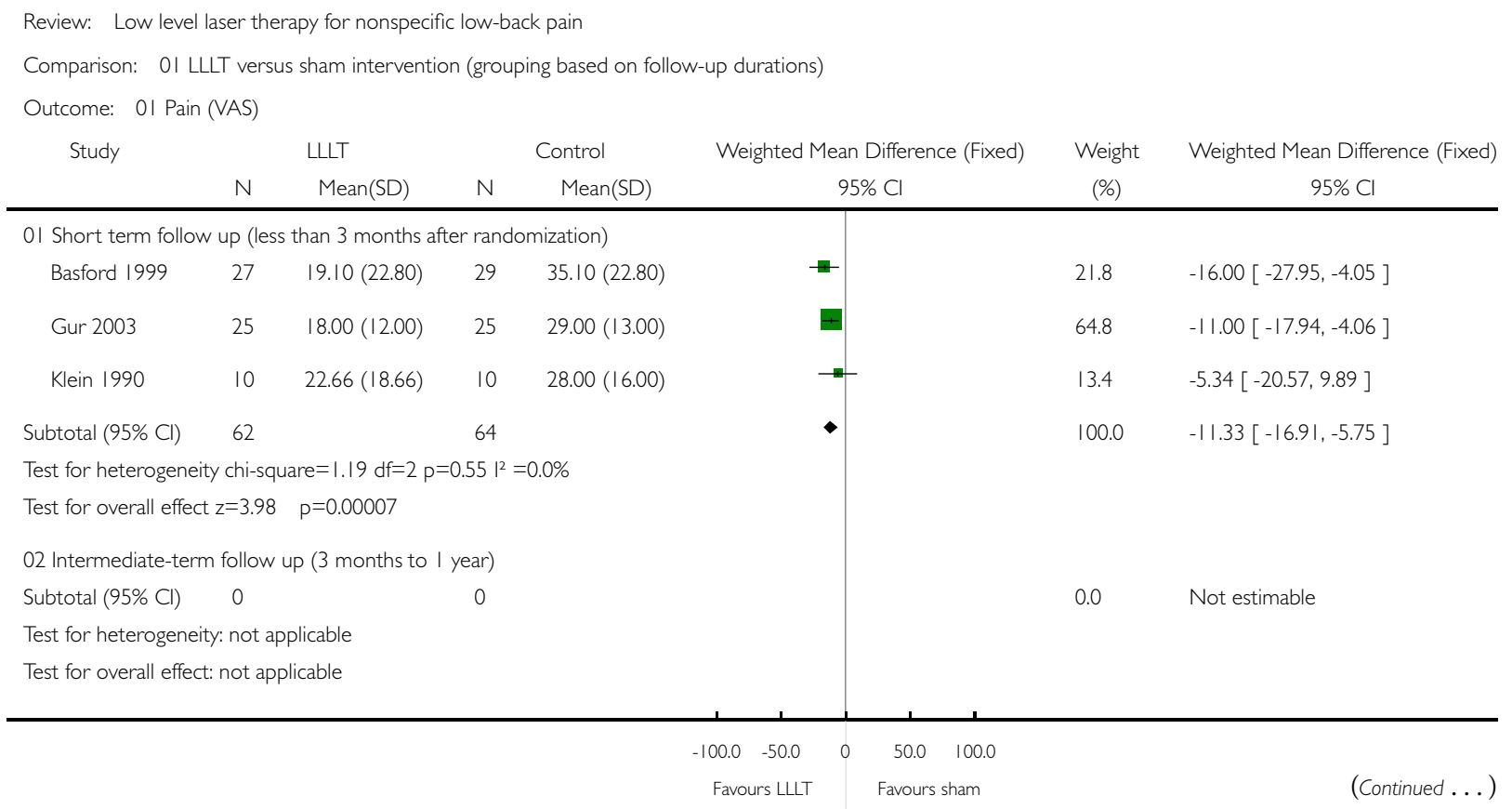


Weighted Mean Difference (Fixed)

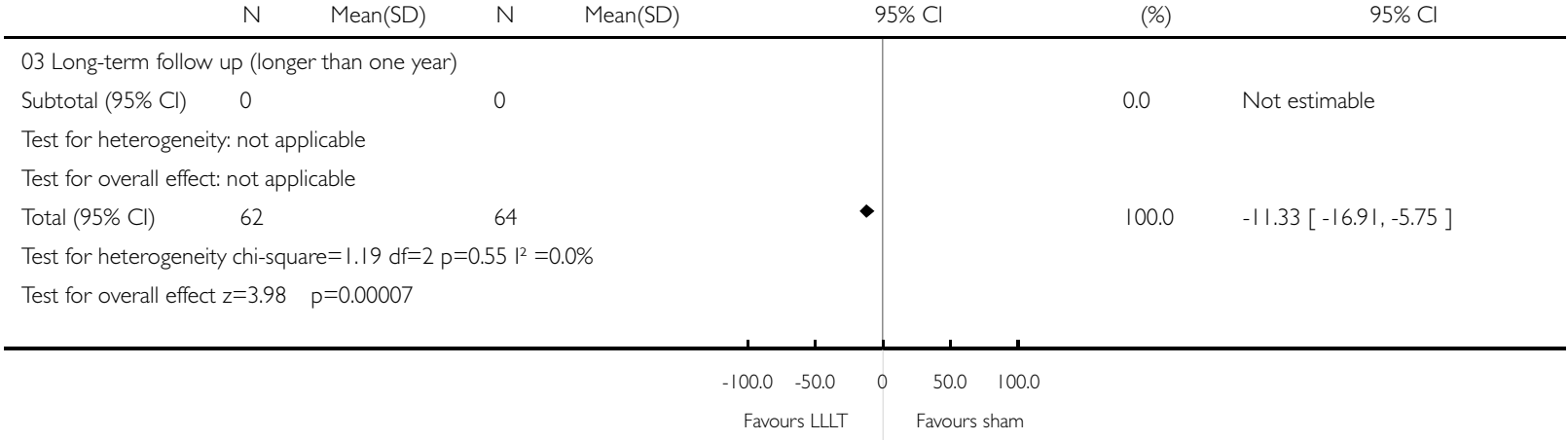

\section{Analysis 01.02. Comparison 0I LLLT versus sham intervention (grouping based on follow-up durations), Outcome 02 Low back pain related disability}

Review: Low level laser therapy for nonspecific low-back pain

Comparison: OI LLLT versus sham intervention (grouping based on follow-up durations)

Outcome: 02 Low back pain related disability

Study LLLT Control Standardised Mean Difference (Random) Weight Standardised Mean Difference (Random) N Mean(SD) N Mean(SD) $95 \% \mathrm{Cl}$ $95 \% \mathrm{Cl}$

0I Short term follow up (less than 3 months after randomization)

Basford $1999 \quad 27 \quad 14.70(10.00) \quad 29 \quad 22.90(10.00)$

$\begin{array}{lllll}\text { Gur } 2003 \quad 25 \quad 14.80(8.60) & 25 & 13.60(7.20)\end{array}$

Klein 1990

$10 \quad 3.60(2.10)$

$10 \quad 2.90(1.60)$

Subtotal $(95 \% \mathrm{Cl}) \quad 62$

64

Test for heterogeneity chi-square $=7.79 \mathrm{df}=2 \mathrm{p}=0.02 \mathrm{I}^{2}=74.3 \%$

Test for overall effect $z=0.38 \quad p=0.7$

02 Intermediate-term follow up (3 months to I year)

Subtotal $(95 \% \mathrm{Cl}) \quad 0 \quad 0$

Test for heterogeneity: not applicable

Test for overall effect: not applicable

03 Long-term follow up (longer than one year)

Subtotal $(95 \% \mathrm{Cl}) \quad 0$

Test for heterogeneity: not applicable

Test for overall effect: not applicable

Total $(95 \% \mathrm{Cl}) \quad 62 \quad 64$

64

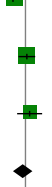

Test for heterogeneity chi-square $=7.79 \mathrm{df}=2 \mathrm{p}=0.02 \mathrm{I}^{2}=74.3 \%$

Test for overall effect $z=0.38 \quad p=0.7$
100.0

ear)

(n)

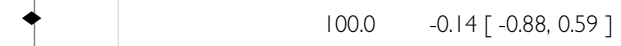

$0.0 \quad$ Not estimable
36.4

36.2

27.4
$0.36[-0.53,1.24]$
$-0.81[-1.36,-0.26]$
$0.15[-0.41,0.70]$
$-0.14[-0.88,0.59]$

0.0 Not estimable

$100.0-0.14[-0.88,0.59]$ 


\section{Analysis 01.03. Comparison 0I LLLT versus sham intervention (grouping based on follow-up durations),}

Outcome 03 Range of motion (Anterior-posterior flexion)

Review: Low level laser therapy for nonspecific low-back pain

Comparison: OI LLLT versus sham intervention (grouping based on follow-up durations)

Outcome: 03 Range of motion (Anterior-posterior flexion)

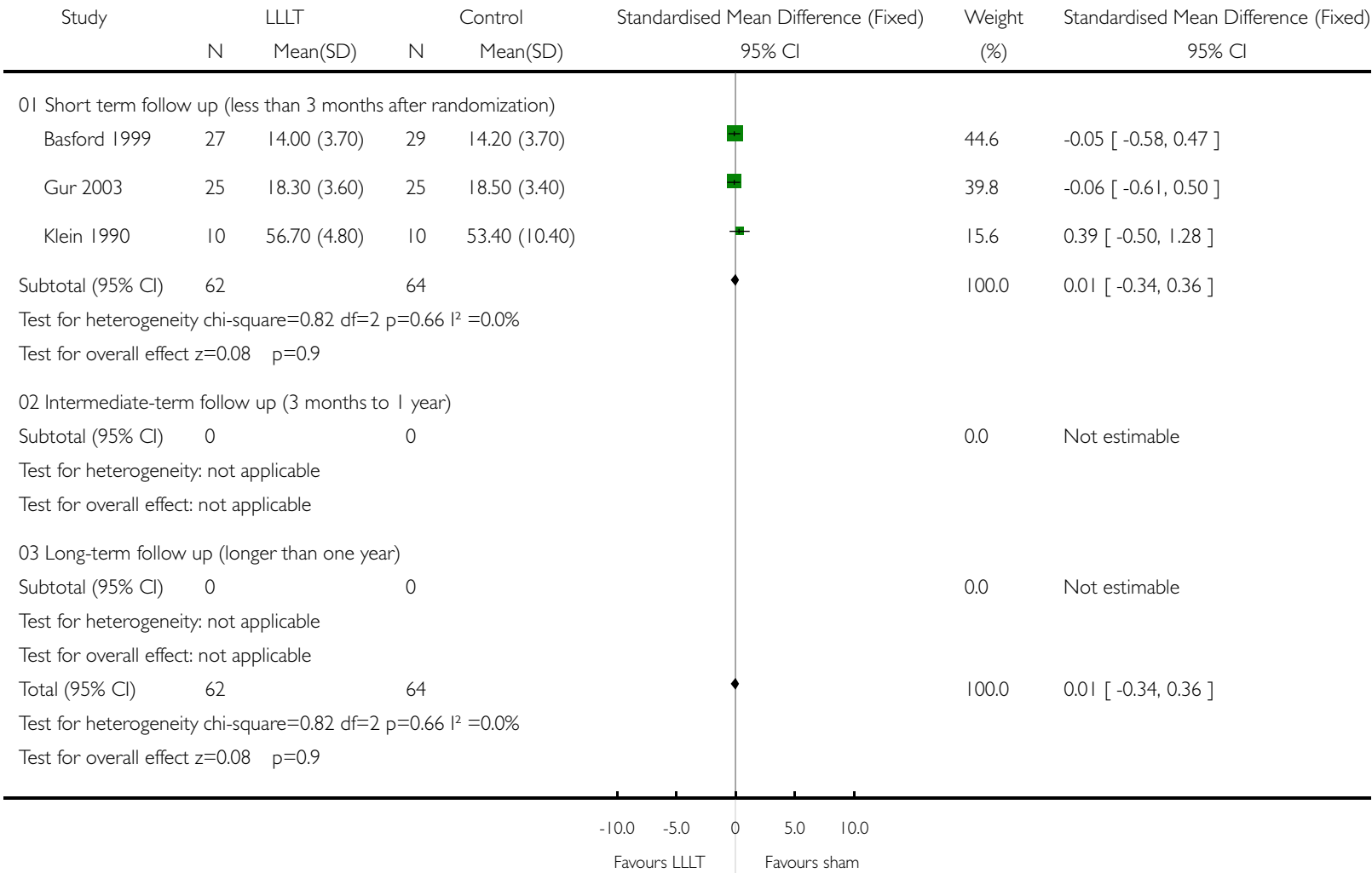




\section{Analysis 01.05. Comparison 0I LLLT versus sham intervention (grouping based on follow-up durations), Outcome 05 Relapse}

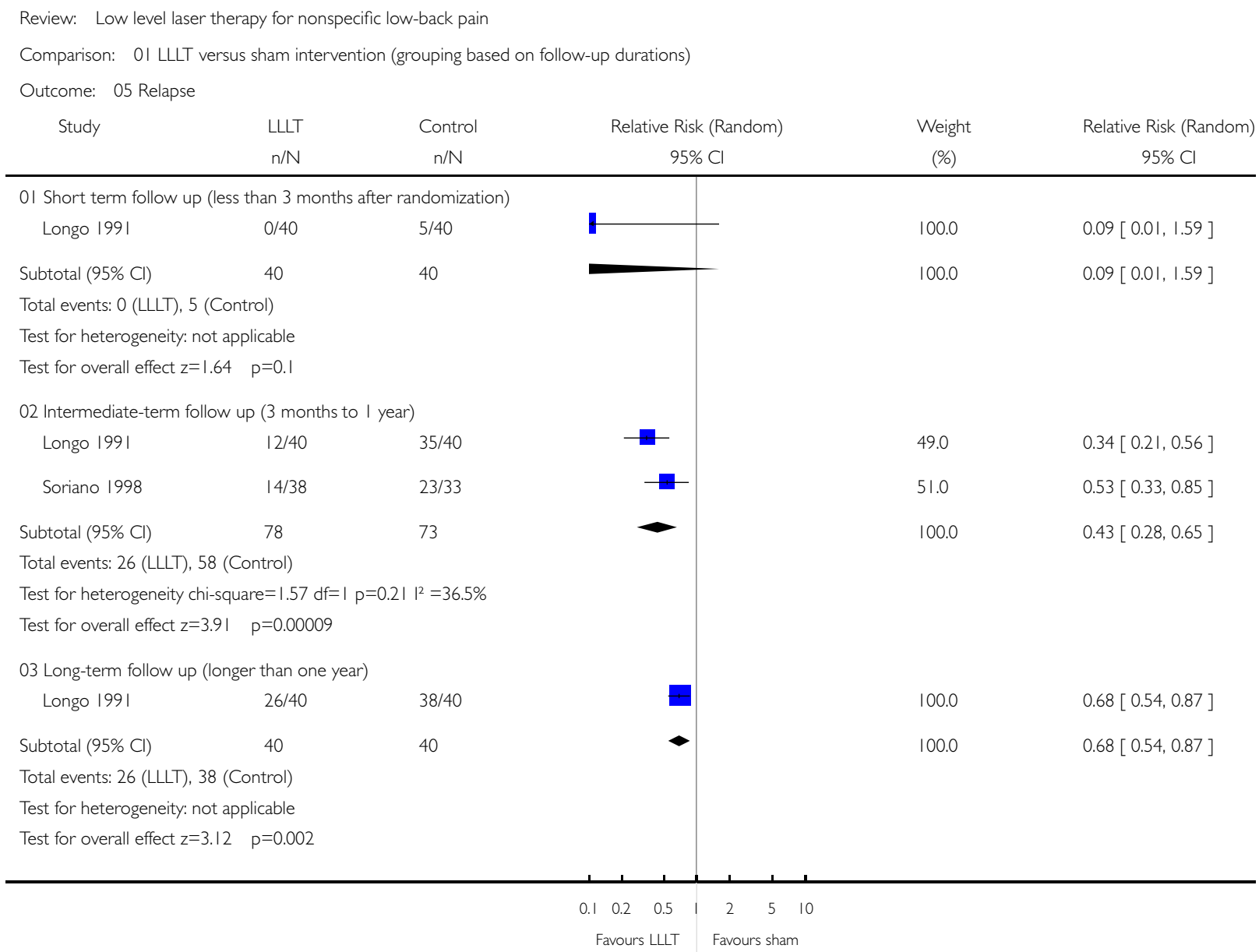




\section{Analysis 02.01. Comparison 02 LLLT versus sham intervention (grouping based on laser dosing), Outcome 0 I Pain(VAS)-short term follow-up}

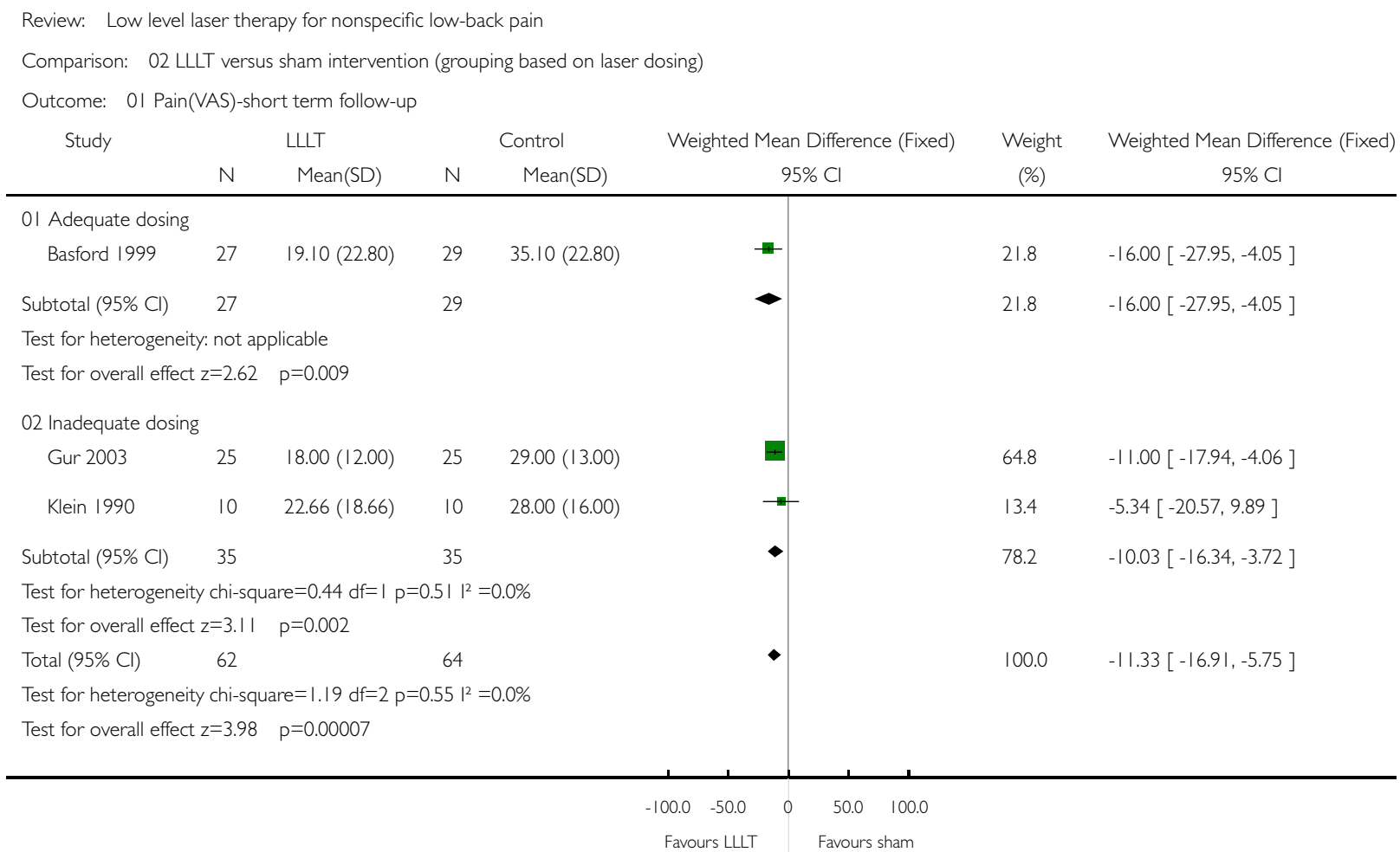


Analysis 02.02. Comparison 02 LLLT versus sham intervention (grouping based on laser dosing), Outcome 02 Low back pain related disability-Short term follow-up

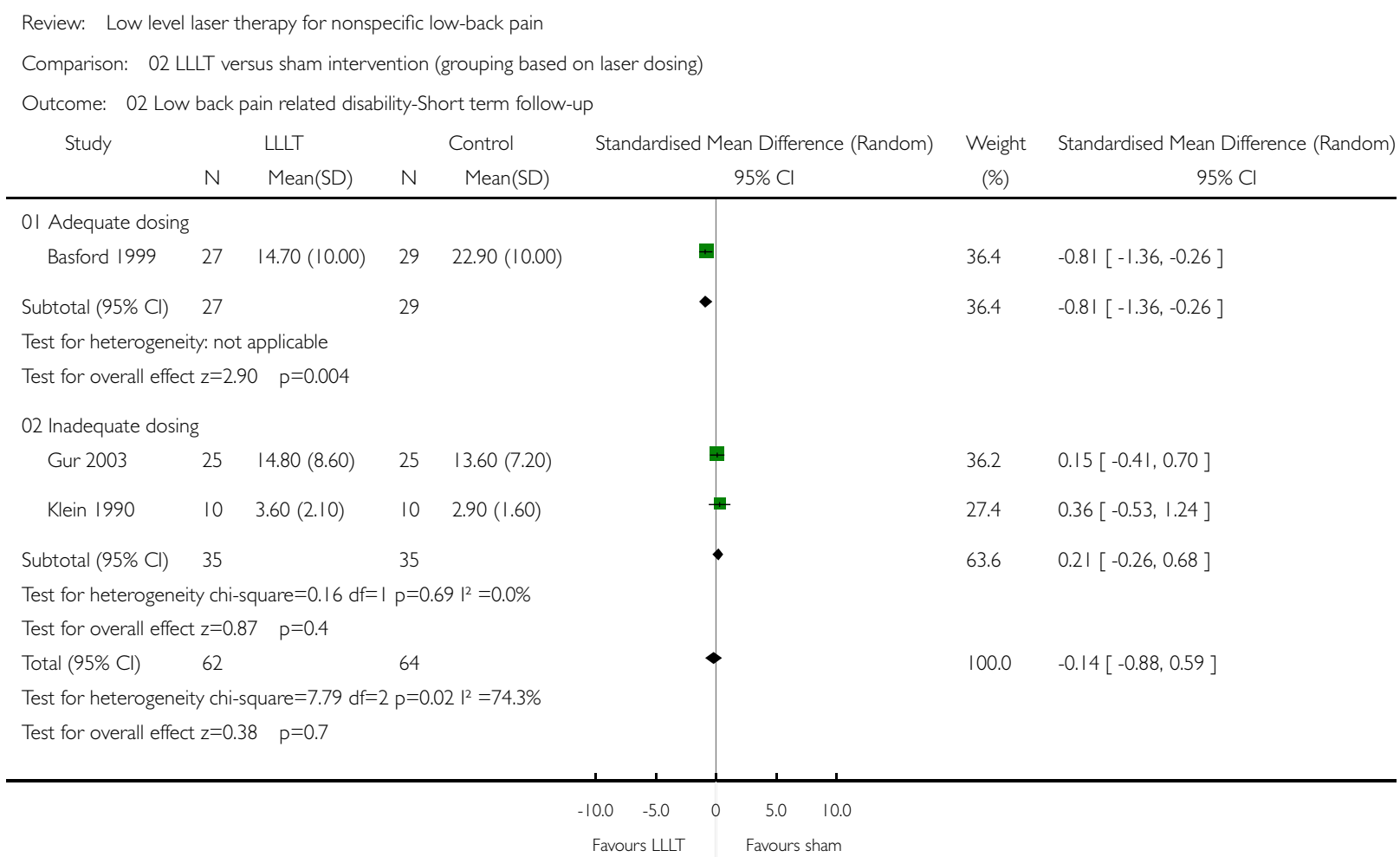


Analysis 02.03. Comparison 02 LLLT versus sham intervention (grouping based on laser dosing), Outcome 03 Range of motion-short term follow-up

\begin{tabular}{|c|c|c|c|c|c|c|c|c|}
\hline \multirow[t]{2}{*}{ Study } & \multicolumn{2}{|c|}{ LLLT } & \multicolumn{2}{|r|}{ Control } & \multirow{2}{*}{\multicolumn{2}{|c|}{$\begin{array}{l}\text { Standardised Mean Difference (Fixed) } \\
\qquad 95 \% \mathrm{Cl}\end{array}$}} & \multirow{2}{*}{$\begin{array}{l}\text { Weight } \\
(\%)\end{array}$} & \multirow{2}{*}{$\begin{array}{l}\text { Standardised Mean Difference (Fixed) } \\
\qquad 95 \% \mathrm{Cl}\end{array}$} \\
\hline & $\mathrm{N}$ & Mean(SD) & $\mathrm{N}$ & Mean(SD) & & & & \\
\hline \multicolumn{9}{|l|}{ OI Adequate dosing } \\
\hline Basford 1999 & 27 & $14.00(3.70)$ & 29 & $14.20(3.70)$ & & + & 44.6 & $-0.05[-0.58,0.47]$ \\
\hline Subtotal $(95 \% \mathrm{Cl})$ & 27 & & 29 & & & $\bullet$ & 44.6 & $-0.05[-0.58,0.47]$ \\
\hline \multicolumn{9}{|c|}{ Test for heterogeneity: not applicable } \\
\hline \multicolumn{9}{|c|}{ Test for overall effect $z=0.20 \quad p=0.8$} \\
\hline \multicolumn{9}{|c|}{02 Inadequate dosing } \\
\hline Gur 2003 & 25 & $18.30(3.60)$ & 25 & I $8.50(3.40)$ & & \# & 39.8 & $-0.06[-0.61,0.50]$ \\
\hline Klein 1990 & 10 & $56.70(4.80)$ & 10 & $53.40(10.40)$ & & - & 15.6 & $0.39[-0.50,1.28]$ \\
\hline Subtotal (95\% Cl) & 35 & & 35 & & & $\bullet$ & 55.4 & $0.07[-0.40,0.54]$ \\
\hline \multicolumn{9}{|c|}{ Test for heterogeneity chi-square $=0.70 \mathrm{df}=\mid \mathrm{p}=0.40 \mathrm{I}^{2}=0.0 \%$} \\
\hline \multicolumn{9}{|c|}{ Test for overall effect $z=0.29 \quad p=0.8$} \\
\hline Total $(95 \% \mathrm{Cl})$ & 62 & & 64 & & & $\bullet$ & 100.0 & $0.01[-0.34,0.36]$ \\
\hline \multicolumn{9}{|c|}{ Test for heterogeneity chi-square $=0.82 \mathrm{df}=2 \mathrm{p}=0.66 \mathrm{I}^{2}=0.0 \%$} \\
\hline Test for overall effec & $z=0.08$ & $p=0.9$ & & & & & & \\
\hline
\end{tabular}


Analysis 02.04. Comparison 02 LLLT versus sham intervention (grouping based on laser dosing), Outcome 04 Relapse-Intermediate term follow-up

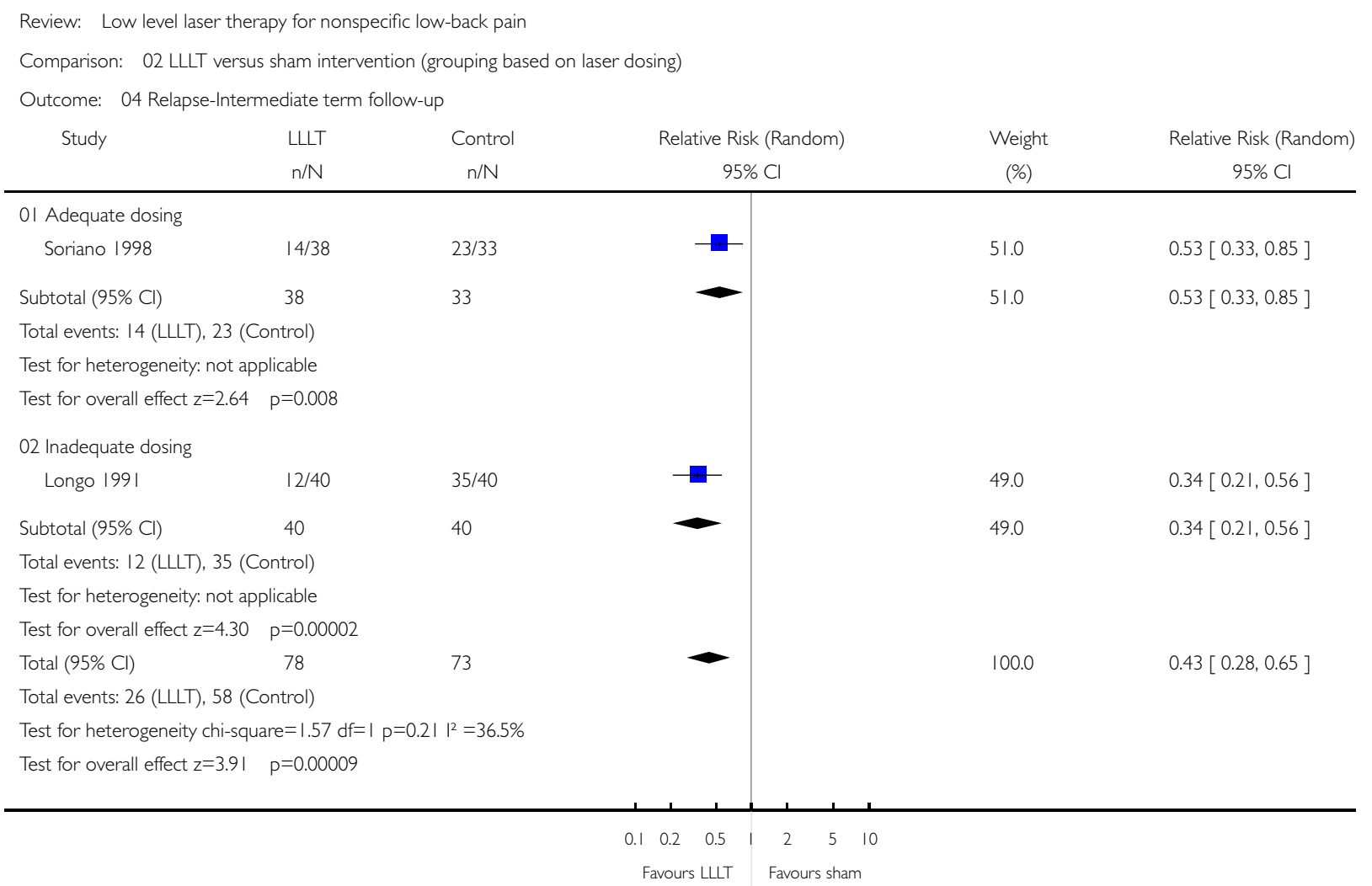


Analysis 03.01. Comparison 03 LLLT versus sham intervention (grouping based on the presence of exercise therapy), Outcome 0 I Pain (VAS)

\begin{tabular}{|c|c|c|c|c|c|c|c|}
\hline \multicolumn{8}{|c|}{ Comparison: 03 LLLT versus sham intervention (grouping based on the presence of exercise therapy) } \\
\hline \multicolumn{8}{|c|}{ Outcome: 0 I Pain (VAS) } \\
\hline \multirow[t]{2}{*}{ Study } & \multicolumn{2}{|r|}{ LLLT } & \multicolumn{2}{|r|}{ Control } & \multirow{2}{*}{$\begin{array}{l}\text { Weighted Mean Difference (Fixed) } \\
\qquad 95 \% \mathrm{Cl}\end{array}$} & \multirow{2}{*}{$\begin{array}{c}\text { Weight } \\
(\%)\end{array}$} & \multirow{2}{*}{$\begin{array}{l}\text { Weighted Mean Difference (Fixed) } \\
\qquad 95 \% \mathrm{Cl}\end{array}$} \\
\hline & N & Mean(SD) & $\mathrm{N}$ & Mean(SD) & & & \\
\hline \multicolumn{8}{|c|}{ 0I LLLT + exercise versus sham + exercise } \\
\hline Gur 2003 & 25 & $18.00(12.00)$ & 25 & $29.00(13.00)$ & + & 64.8 & $-11.00[-17.94,-4.06]$ \\
\hline Klein 1990 & 10 & $22.66(18.66)$ & 10 & $28.00(16.00)$ & $\rightarrow$ & 13.4 & $-5.34[-20.57,9.89]$ \\
\hline Subtotal $(95 \% \mathrm{Cl})$ & 35 & & 35 & & $\bullet$ & 78.2 & $-10.03[-16.34,-3.72]$ \\
\hline \multicolumn{8}{|c|}{ Test for heterogeneity chi-square $=0.44 \mathrm{df}=\mid \mathrm{p}=0.5 \mathrm{|} \mathrm{I}^{2}=0.0 \%$} \\
\hline \multicolumn{8}{|c|}{ Test for overall effect $z=3.11 \quad p=0.002$} \\
\hline \multicolumn{8}{|c|}{02 LLLT versus sham } \\
\hline Basford 1999 & 27 & $19.10(22.80)$ & 29 & $35.10(22.80)$ & 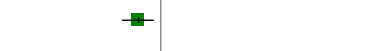 & 21.8 & $-16.00[-27.95,-4.05]$ \\
\hline Subtotal $(95 \% \mathrm{Cl})$ & 27 & & 29 & & - & 21.8 & $-16.00[-27.95,-4.05]$ \\
\hline \multicolumn{8}{|c|}{ Test for heterogeneity: not applicable } \\
\hline \multicolumn{8}{|c|}{ Test for overall effect $z=2.62 \quad p=0.009$} \\
\hline Total $(95 \% \mathrm{Cl})$ & 62 & & 64 & & • & 100.0 & $-11.33[-|6.9|,-5.75]$ \\
\hline \multicolumn{8}{|c|}{ Test for heterogeneity chi-square $=1.19 \mathrm{df}=2 \mathrm{p}=0.55 \mathrm{I}^{2}=0.0 \%$} \\
\hline Test for overall effe & $z=3.98$ & $p=0.00007$ & & & & & \\
\hline
\end{tabular}


Analysis 03.02. Comparison 03 LLLT versus sham intervention (grouping based on the presence of exercise therapy), Outcome 02 Low back pain related disability

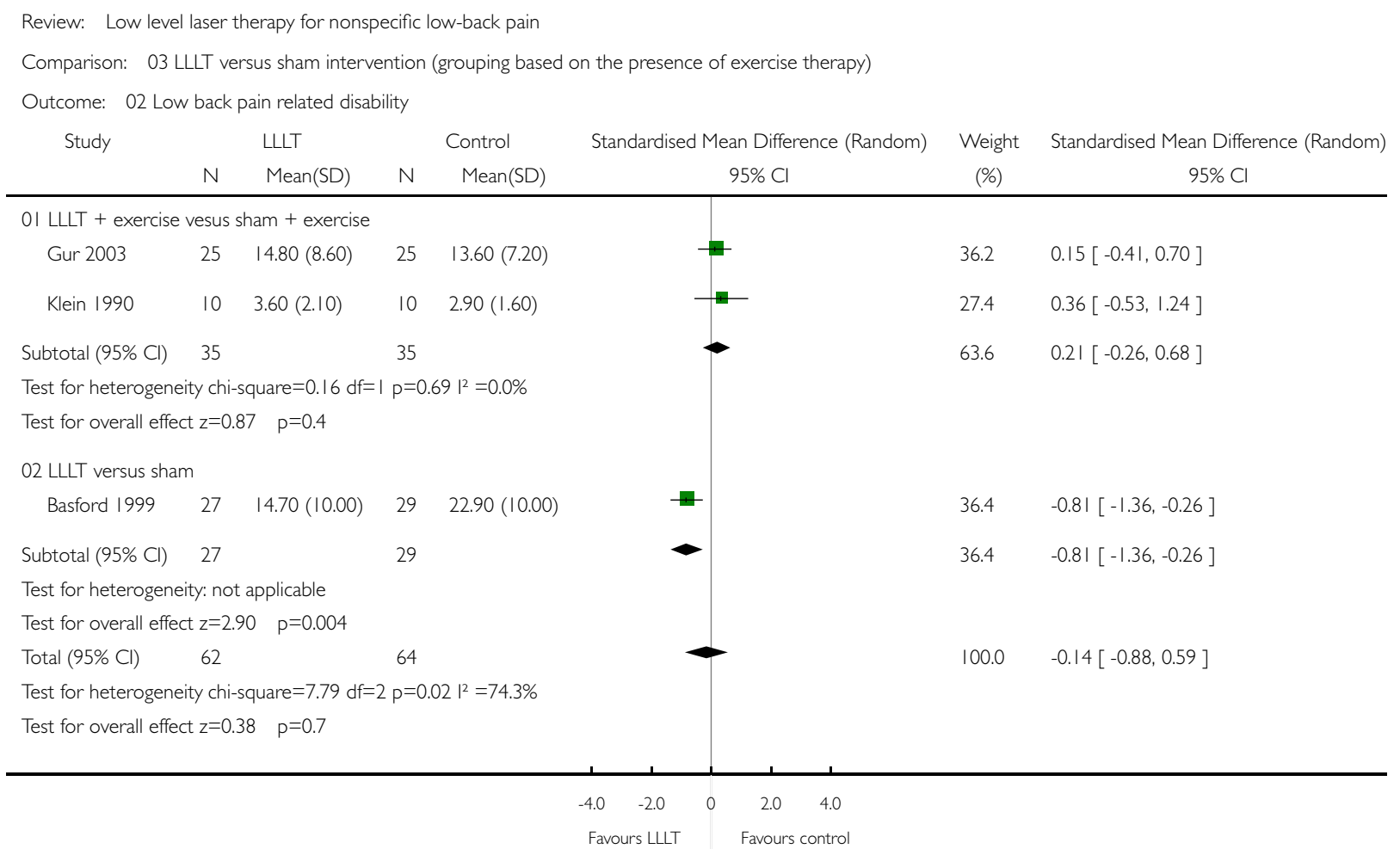


Analysis 03.03. Comparison 03 LLLT versus sham intervention (grouping based on the presence of exercise therapy), Outcome 03 Range of motion (Anterior-posterior flexion)

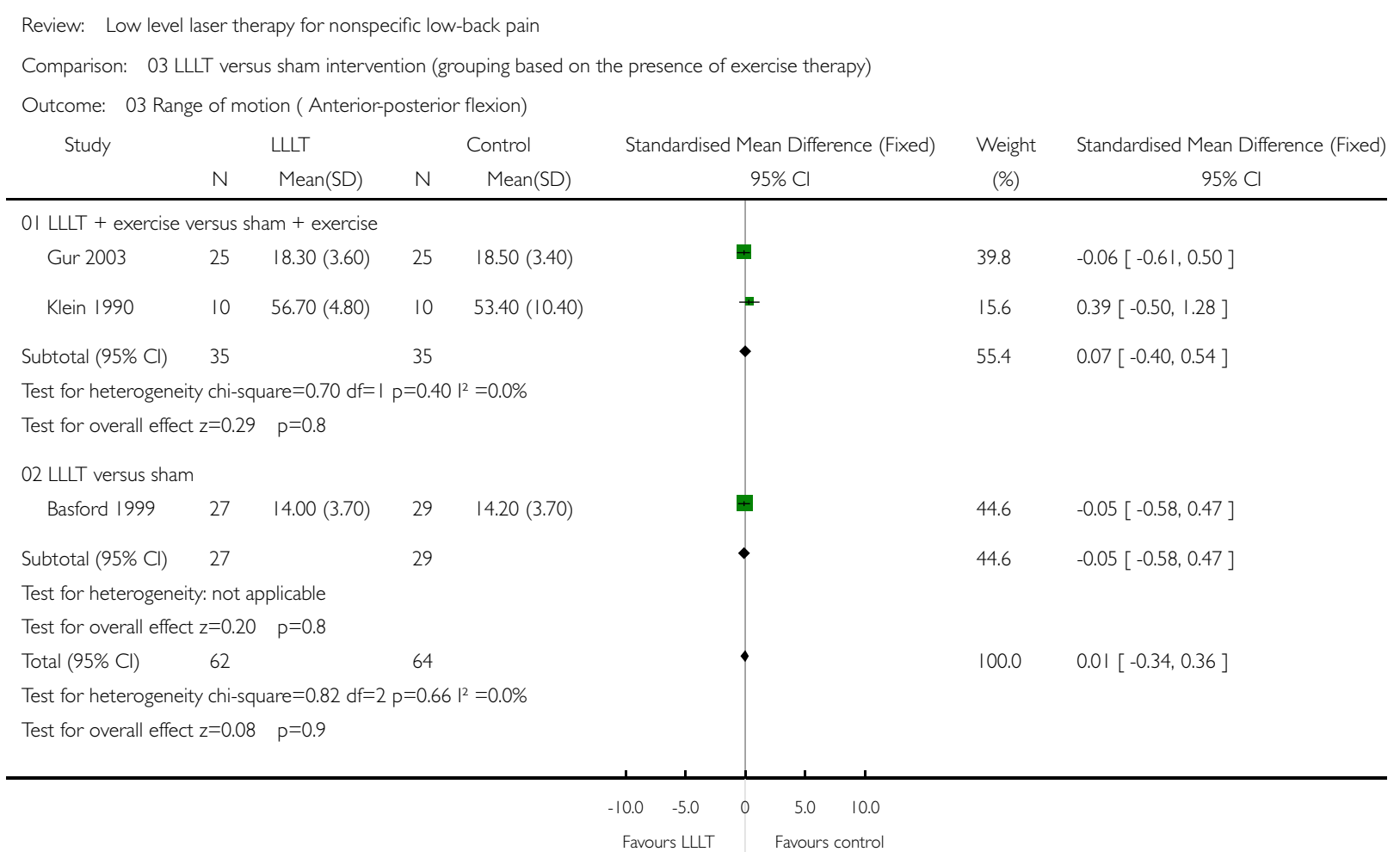

